\title{
IN THE STATIONHOUSE AFTER DICKERSON
}

\author{
Charles D. Weisselberg*
}

INTRODUCTION

Miranda $v$. Arizona ${ }^{1}$ established the high water mark of the protections afforded an accused during a custodial interrogation. During the decades that followed, the United States Supreme Court allowed Miranda's foundation to erode, inviting a direct challenge to the landmark ruling. In Dickerson v. United States, ${ }^{2}$ the Court turned back such a challenge and placed Miranda upon a more secure, constitutional footing. This Article explores the impact of Dickerson in the place where Miranda was meant to matter most: the stationhouse.

As I have described elsewhere, Supreme Court decisions have influenced a number of California law enforcement agencies to instruct officers that they may continue to interrogate suspects in custody who have asserted their Fifth Amendment right to remain silent or right to counsel. ${ }^{3}$ Harris $v$. New York ${ }^{4}$ and Oregon $v$. Hass ${ }^{5}$ permit some statements taken in violation of Miranda to be used for impeachment purposes at trial. Michigan v. Tucker ${ }^{6}$ and Oregon v. Elstad ${ }^{7}$ permit some

* Professor of Law and Director, Center for Clinical Education, University of California at Berkeley (Boalt Hall) School of Law. - Ed.

I am grateful to Evan Caminker, Margaret Dundon, Richard Leo, Kay Levine, Robert Post, Mark Rosenbaum, Stephen Sugarman, and participants at the University of Michigan Law Review's Symposium and Boalt Hall's Center for Social Justice workshop for their advice and assistance. I owe particular debts to Yale Kamisar for inspiring me (and others) to study interrogation practices and to Andrew Stein for first introducing me to police training in California.

Together with my colleagues and students, I have served as co-counsel for the plaintiffsappellees in Cal. Att'ys for Crim. Justice v. Butts, 195 F.3d 1039 (9th Cir. 1999) and for amici curiae in People v. Peevy, 953 P.2d 1212 (Cal. 1998) and Dickerson v. United States, 120 S. Ct. 2326 (2000). A law student, Victoria Wong, argued Butts under my supervision. My work in these cases has shaped many of my views, but the opinions expressed here (and, of course, any errors) are my own.

1. 384 U.S. 436 (1966).

2. 120 S. Ct. $2326(2000)$. (1998).

3. See Charles D. Weisselberg, Saving Miranda, 84 CORNELL L. REv. 109, 126-40
4. 401 U.S. 222 (1971).
5. 420 U.S. 714 (1975).
6. 417 U.S. 433 (1974).
7. 470 U.S. 298 (1985). 
derivative use of such statements. ${ }^{8}$ These rulings - together with other decisions labeling Miranda's procedures as merely "prophylactic"9 - have created incentives for police to disregard Miranda and have led to a different way of thinking about its core holding. Proponents of this different view, which I have called the "new vision" of Mirand $a,{ }^{10}$ have claimed that Miranda sets forth a nonconstitutional rule of evidence that need only be followed when officers seek a statement to introduce in the prosecution's case-in-chief at trial. ${ }^{11} \mathrm{By}$ transforming Miranda from an affirmative constitutional command governing conduct in the stationhouse into a weak rule of evidence, the new vision has encouraged officers to continue to question suspects who have asserted the right to counsel or the right to remain silent. During the last decade, the practice has become so pervasive in some jurisdictions that it has acquired its own moniker: questioning "outside Miranda." 12

This Article argues that Dickerson firmly rejects the "new vision" and asks whether the ruling may foster new respect for Miranda and adherence to its commands. The Article explores the Court's reaffirmation of the constitutional basis for Miranda and discusses the efficacy of exclusionary rules and civil rights actions in enforcing Miranda's procedures. Most police officers are not lawyers and do not read advance sheets. Court decisions can influence officers' conduct only if the holdings are accurately transmitted to them. This Article thus examines how law enforcement officials are instructed following Dickerson and other recent Miranda cases, and explores whether officers are likely to follow their training.

Part I briefly reviews interrogation training in the last decade, particularly in California, and discusses the holdings in Dickerson and three other recent Miranda decisions from lower courts, including one civil rights action. Part II examines the instruction of officers in California in the wake of these cases. Although the training is not uniform, and may not be given in all parts of California, officers are now being encouraged to comply with Miranda. It appears to have taken a palpable threat of civil liability and, perhaps, Dickerson to force this change. Part III discusses the conditions under which the new training may actually alter interrogation practices in the stationhouse. The Article argues that the new training may prove effective if law en-

8. In Tucker, the Court declined to suppress the testimony of a trial witness whose identity was discovered through a statement in violation of Miranda. 417 U.S. at 450 . In Elstad, the Court ruled that a statement given after proper warnings would not be suppressed as the fruit of an earlier unwarned statement. 470 U.S. at 309.

9. E.g., Duckworth v. Eagan, 492 U.S. 195, 203 (1989); Tucker, 417 U.S. at 446.

10. Weisselberg, supra note 3 , at 132.

11. See id. at $132-40$.

12. See id. at 133-37. 
forcement supervisors themselves take Miranda's commands seriously and work to change norms within their departments. Finally, the Article explores the use of civil rights actions to vindicate Miranda rights after Dickerson and concludes that the risk of civil rights liability is important in changing departmental norms.

\section{INTERROGATION PRACTICES, THE COURTS AND DICKERSON}

\section{A. Questioning "Outside Miranda" in California}

Before describing police practices in California, one might ask whether it is worth examining what occurs in a single state and whether California's practices have spread to other jurisdictions. There is some evidence of Miranda noncompliance outside of California ${ }^{13}$ though I have not undertaken to examine training in other jurisdictions and I make no claims about the prevalence of questioning "outside Miranda" elsewhere. Nevertheless, even in the event that questioning "outside Miranda" is confined to California, California is the nation's most populous state $^{14}$ and has the largest criminal justice system of all the states. ${ }^{15}$ Whether or not California's police practices are representative of those in other jurisdictions, California has a large chunk of the nation's criminal investigations and prosecutions, and what happens in California is therefore significant in its own right.

Consistent with the "new vision" of Miranda, many police officers in California have been trained during the last decade that Miranda's rules are merely nonconstitutional "recommended" or "suggested" guidelines that must be followed only when officers seek a statement

13. See Weisselberg, supra note 3 , at $137-38$ (collecting cases); see also United States v. Acosta, 111 F. Supp. 2d 1082, 1088 (E.D. Wis. 2000) (describing plan by FBI agent to ignore requests for counsel); Hendrickson v. State, 688 S.W.2d 295 (Ark. 1985) (officers deliberately questioned over an invocation of the right to counsel); State v. Burris, 679 A.2d 121, 124-25 (N.J. 1996) (police interrogated suspect despite clear invocation of right to counsel); State v. Sosinski, 750 A.2d 779, $782-83$ (N.J. Super. Ct. App. Div. 2000) (prosecutors instructed officers not to Mirandize suspect so that he would think he was not in custody); Peter Erlinder, Getting Serious About Miranda in Minnesota: Criminal and Civil Sanctions for Failure to Respond to Requests for Counsel, 27 WM. MITCHELL L. REV. 941, 964-67 (2000) (describing refusal of FBI agent to respect assertion of right to counsel).

14. In 2000 , the population of California was $33,871,648,12 \%$ of the total population of the United States. See U.S. Census Bureau, Tbl. 2, Resident Population of the 50 States, the District of Columbia, and Puerto Rico: Census 2000, available at http://www.census.gov/population/www/cen2000/respop.html\#t2 (last visited Apr. 20, 2001).

15. In 1998 , California law enforcement officials made $1,565,431$ nontraffic arrests $(15 \%$ of the $10,291,317$ nontraffic arrests made by all the states), including 340,602 arrests for FBI index crimes ( $19 \%$ of the $1,774,193$ arrests for FBI index crimes made by all states). See FED. Bureau of INVEST., U.S. DEP'T OF JustiCE, UNIF. CRIME REPS., CRIME IN THE UNITED STATES (1998) tbl. 30 (Arrests, Number and Rate) \& tbl. 69 (Arrests by State). "Index" crimes include murder, nonnegligent manslaughter, forcible rape, robbery, aggravated assault, burglary, larceny-theft, motor vehicle theft and arson. 
that will be admissible in the prosecution's case-in-chief at trial. ${ }^{16}$ This training has been promulgated by state law enforcement agencies, such as the Attorney General's office and the California Commission on Peace Officer Standards and Training ("POST"). ${ }^{17}$ The instruction has also occurred in counties and cities within California, though it is also true that some agencies have rejected the practice and have told officers to respect a suspect's Miranda invocation. ${ }^{18}$ Despite the efforts of some agencies to urge respect for Miranda, "outside Miranda" training has had a significant impact in California, as demonstrated by the reported cases with "outside Miranda" issues. ${ }^{19}$ This training has led to several legislative efforts at reform, which have not yet proved successful. ${ }^{20}$

"Outside Miranda" instruction emphasizes that Miranda describes only a value-neutral rule of evidence; it does not embody a constitutional command. Thus, there is nothing legally or morally wrong in interrogating a suspect who has invoked the right to counsel or the right to remain silent. Questioning over an invocation merely has an evidentiary consequence at trial. ${ }^{21}$ It is therefore perfectly legitimate to ques-

16. See Weisselberg, supra note 3, at 133-37. In Tucker, the Court called Miranda's safeguards "recommended" and "suggested," though it is clear from the context that the Court did not mean that Miranda's procedures could be unilaterally scrapped. See Tucker, 417 U.S. at $443-44$.

17. See Weisselberg, supra note 3, at 133-34. POST is part of the California Department of Justice. See CAL. PENAL CODE $\$ 13500$ (2000). It develops training programs and standards for law enforcement officers. See CAL. PENAL CODE $\$ \S 13503(\mathrm{e})(2000), 13510(\mathrm{a})$ (2000 \& Supp. 2001), 13511 (2000 \& Supp. 2001).

18. See infra Section II.C.

19. See infra Section I.B; see also Weisselberg, supra note 3, at 136-37. There are no empirical studies showing the prevalence of this practice in police departments throughout California. In 1992-93, however, Richard Leo observed 182 interrogations conducted by police in three northern California departments. Suspects invoked their rights in thirty-eight interrogations. Officers continued to question "outside Miranda" in seven of those thirtyeight cases (18\%). See Richard A. Leo, Inside the Interrogation Room, 86 J. CRIM. L. \& CRIMINOLOGY 266, 276 (1996).

20. In 1999, a bill was introduced in the California State Assembly declaring "the intent of the Legislature" that officers cease questioning a suspect in custody who has invoked his or her Miranda rights. A.B. 1326, 1999-2000 Reg. Sess. (Cal., as amended Jan. 14, 2000). The bill was voted out of committee but died while Dickerson was pending in the Supreme Court. On March 19, 2001, another bill was introduced in the California State Senate with the same declaration, but also with a provision to prohibit "outside Miranda" training. See S. B. 1211, 2001-02 Reg. Sess. (Cal., as amended May 15, 2001). The bills and their histories are available at http://www.assembly.ca.gov/acs/acsframeset2text.htm (last visited May 29, 2001).

21. See, e.g., Cal. DeP'T OF Justice, California PEACE OfFicers Legal SOURCEBOOK $\$ 7.40$ a (Rev. Mar. 1997) [hereinafter SOURCEBOOK] (on file with author) ("An uncoerced (voluntary) statement obtained 'outside' Miranda (without complying with Miranda) may not be used during trial as part of the prosecutor's case-in-chief. ... However, it can be used during the 'rebuttal' portion of the trial to impeach a defendant. ..."); id., $\$ 7.40 \mathrm{~b}$ ("[T]he Miranda decision is not a code of conduct setting forth how police must conduct their investigations in the field. . . . Rather, the Miranda opinion simply sets out a 'series of recommended "procedural safeguards"....") (quoting Tucker, 417 U.S. at 443-44); Videotape: Questioning: "Outside Miranda" (Greg Gulen Productions 1990), transcript re- 
tion a suspect even after she has asserted her Fifth Amendment rights, to obtain additional information (such as the location of physical evidence, the names of witnesses, the identities of accomplices, or the accused's methods of operation) or to force the defendant to commit to a statement that will prevent her from asserting a new defense at trial. Of course, any such statement cannot itself be used in the case-in-chief at trial. But, in the words of a proponent of this tactic, "you can accomplish all of these legitimate purposes that don't have anything to do with the prosecution of the case, and some that do, by talking to the guy 'outside Miranda.' "22 Officers trained in this fashion perceive no downside to questioning "outside Miranda." Investigators who respect an invocation of a suspect's rights and stop questioning will obtain no information from a suspect. On the other hand, questioning over an invocation may yield useful information, even if that information has a limited use at trial.

I have argued elsewhere that this theory and training is not faithful to the language, history, or purposes of Miranda. ${ }^{23}$ Nor does it cohere with Edwards v. Arizona, ${ }^{24}$ which holds that an accused who has "expressed his desire to deal with the police only through counsel ... is not subject to further interrogation by the authorities until counsel has been made available to him" unless the suspect reinitiates contact or communication with the officers. ${ }^{25}$ A significant number of law enforcement trainers, however, have not read Miranda or Edwards to bar such continued questioning. ${ }^{26}$

printed in Weisselberg, supra note 3, at 191:

The Miranda exclusionary rule is limited to the defendant's own statement out of his mouth. That is all that is excluded under Miranda. It doesn't have a fruits of the poisonous tree theory attached to it the way constitutional violations do. When you violate Miranda, you're not violating the Constitution. Miranda is not in the Constitution. It's a court-created decision that affects the admissibility of testimonial evidence and that's all it is. So you don't violate any law. There's no law says [sic] you can't question people "outside Miranda." You don't violate the Constitution. The Constitution doesn't say you have to do that. It's a court decision. So all you're violating is a court decision controlling admissibility of evidence. So you're not doing anything unlawful, you're not doing anything illegal, you're not violating anybody's civil rights, you're doing nothing improper. The only consequence of your talking to somebody who has invoked his rights is we will not be able to use his statement in the case in chief in trial against him.

22. See id. at 192.

23. See Weisselberg, supra note 3 , at 122-25, 140-53, 162-67.

24. 451 U.S. 477 (1981).

25. Id. at 484-85; see also Minnick v. Mississippi, 498 U.S. 146, 153 (1990) (holding that Edwards' protection does not cease once a suspect actually consults with counsel).

26. This narrow reading of Miranda and Edwards is not confined to law enforcement. See Arnold H. Loewy, Police-Obtained Evidence and the Constitution: Distinguishing Unconstitutionally Obtained Evidence from Unconstitutionally Used Evidence, $87 \mathrm{MICH}$. L. REV. 907, 916-28 (1989) (arguing that the Fifth Amendment can only be violated at trial and, hence, courts should care only about the admission of Miranda-violative statements, not whether Miranda is breached in the stationhouse). 


\section{B. Lower Court Rulings and Questioning "Outside Miranda"}

Because so many officers have been instructed that it is permissible to interrogate "outside Miranda," a series of cases challenging this practice have reached the state and federal courts. Along with Dickerson, these decisions have significantly affected formal police training in California.

\section{People v. Peevy}

A number of defendants have argued to California state courts that statements taken in deliberate violation of Miranda and Edwards should not be admissible for impeachment under Harris v. New York and that the tactic of questioning "outside Miranda" was sufficient to render their statements involuntary under the Fourteenth Amendment. An involuntary statement is inadmissible for any purpose, including impeachment. ${ }^{27}$ Most intermediate appellate courts to face the issue have strongly criticized the practice of questioning "outside Miranda." 28 But not all intermediate appellate courts agreed. In People v. Branscombe, ${ }^{29}$ the court endorsed the "new vision" of Miranda, holding that "[p]olice officers are presented with a choice they may cease questioning upon defendant's invocation of the right to remain silent or they may continue their discussion with the suspect and therefore lose the benefit of that evidence in the prosecution's case-in-chief." 30

The question reached the California Supreme Court in 1998 in People v. Peevy. ${ }^{31}$ Airreque Peevy was arrested for attempted robbery

\section{See Mincey v. Arizona, 437 U.S. 385, 398 (1978).}

28. See, e.g., In re Gilbert E., 38 Cal. Rptr. 2d 866, 868 (Ct. App. 1995) ("When the police deliberately step over the line and disobey Supreme Court pronouncements, respect for the rule of law necessarily diminishes."); People v. Bey, 27 Cal. Rptr. 2d 28, 30-31 (Ct. App. 1993) ("This is a very troubling case, presenting a deliberate police violation of Miranda coupled with a misrepresentation to appellant about the legal consequences of that violation."); People v. Montano, 277 Cal. Rptr. 327, 337 (Ct. App. 1991) ("No tolerance can be given to the officers' flagrant trampling of defendant's rights, particularly because [officers] began the interrogation with no intention of respecting those rights." (footnote omitted)); People v. Baker, 269 Cal. Rptr. 475, 478 (Ct. App. 1990) ("Fortunately, the trial court here was well aware of the unlawfulness of the police conduct and stated that it intended to initiate steps to prohibit the San Diego Police Department from using ["outside Miranda"] procedures in the future."). 1998).

29. 72 Cal. Rptr. 2d 773 (Ct. App. 1998), depublished, 1998 Cal. LEXIS 4252 (June 24,

30. Id. at 778 .

31. 953 P.2d 1212 (Cal. 1998), cert. denied, 525 U.S. 1042 (1998). In a death penalty case decided a year earlier, the California Supreme Court noted that officers had questioned the defendant after his request for counsel. See People v. Bradford, 929 P.2d 544 (Cal. 1997). The court criticized the officers, stating that their conduct "was unethical and it is strongly disapproved." Id. at 567. 
by San Bernardino County sheriff's deputies, who questioned him after he asked for an attorney. ${ }^{32}$ One deputy testified that "I kept talking with him for impeachment purposes." 33 Peevy's "outside Miranda" statement was later used to impeach him at trial. ${ }^{34}$

On May 7, 1998, the California Supreme Court unanimously ruled that the Harris exception applies even when a statement is taken in deliberate violation of Miranda and Edwards. ${ }^{35}$ Peevy did not assert that his statement was involuntary; consequently, that issue was not addressed ${ }^{36}$ The court also left open the question whether a statement would still be admissible for impeachment if there was proof of a widespread practice on the part of the police to ignore a Miranda invocation. ${ }^{37}$

Though Peevy permits the impeachment use of a statement taken deliberately "outside Miranda," all seven justices also unequivocally rejected the claim that Miranda and Edwards merely establish a valueneutral rule of evidence that may be disregarded at an officer's election. Those cases impose "an affirmative duty upon interrogating officers to cease questioning once a suspect invokes the right to counsel... Nothing in the language of Harris or Oregon v. Hass, for example, suggests that the court now considers the Miranda or Edwards rules as constituting mere advice regarding preferred police conduct." ${ }^{38}$ The court declared that a statement is excluded under Mirand $a$ and Edwards because "the evidence was obtained illegally" 39 and described questioning after an invocation as "police misconduct." ${ }^{40}$ Soon thereafter, the justices also "depublished" Branscombe, removing its ability to serve as precedent. ${ }^{41}$

Peevy filed a petition for writ of certiorari. In its response, the California Attorney General asked the U.S. Supreme Court to take

32. See Peevy, 953 P.2d at 1215.

33. Id.

34. See id. at 1216.

35. See id. at 1219. Part of the reason for the holding is that, under the California Constitution, statements taken in violation of Miranda may be excluded only to the extent required by the federal Constitution. See id. at 1214.

36. See id. at $1221 \mathrm{n} .2$.

37. See id. at 1225-28. The court declined to take judicial notice of "outside Miranda" training materials because the issue of police training was not raised in the trial court and because the materials did not specifically pertain to the San Bernardino County Sheriff's office. See id. at 1227 n.4. Justice Stanley Mosk wrote separately to indicate that if the defendant had established that he was questioned pursuant to a policy to violate Miranda, his statement would not be admissible under Harris. See id. at 1228-32 (Mosk, J., concurring).

38. Id. at 1224 (citation omitted).

39. Id. at 1225.

40. Id.

41. People v. Branscombe, 1998 Cal. LEXIS 4252 (June 24, 1998). An unpublished opinion "shall not be cited or relied on by a court or a party." CAL. R. CT. 977(a). 
the case and "once and for all clarify that non-coercive noncompliance with Miranda does not constitute 'illegal' or 'unlawful' conduct. ${ }^{\prime 2}$ On December 7, 1998, the Court denied the petition. ${ }^{43}$

Peevy contains an unambiguous statement from California's highest court, decrying the practice of questioning over a Miranda invocation. But the overall message to officers was muddied. By holding that statements taken in deliberate violation of Miranda are still admissible for impeachment, the court left wholly intact the incentive for officers to continue to violate Miranda and, perhaps, gave the impression that state courts would be willing to look the other way.

\section{Henry v. Kernan}

As one might also expect, issues about these interrogation practices eventually reached the federal circuit court. On May 26, 1999, the court of appeals decided Henry $v$. Kernan ${ }^{44}$ reversing the denial of a habeas corpus petition in a second-degree murder case. Henry was interrogated by Sacramento County sheriff's deputies after he asked for counsel. Shaken, confused and frightened, he gave a rambling and disjointed statement, which was used to impeach him at trial. ${ }^{45}$

In granting relief, the Ninth Circuit noted that the officers' refusal to honor Henry's invocation "was designed to generate a feeling of helplessness," and "it was successful." ${ }^{46}$ The court concluded that "the slippery and illegal tactics" of the officers overcame Henry's will and made his statements involuntary and thus inadmissible for any purpose. ${ }^{47}$ In addition to questioning after his invocation of the right to counsel, one of the deputies misled Henry about the effect of a statement, saying that "what you tell us we can't use against you right now.... We'd just would like to know." 48

The State sought rehearing in Henry, arguing that Henry's statements were voluntary up to the point that the misleading assurances were given. Denying rehearing, the court strengthened its opinion,

42. Response to Petition for Writ of Certiorari at 12, Peevy v. California (No. 98-6125) (Nov. 6, 1998). Professor Paul G. Cassell and the Washington Legal Foundation also asked the Supreme Court to take the case, stating that " $[a]$ mici are deeply concerned that the conclusion below about the 'illegality' of noncoercive questioning outside of the Miranda rules will unnecessarily discourage police officers from questioning suspects ...." Brief of Amici Curiae Washington Legal Foundation et al. at 2, Peevy v. California (No. 98-6125) (Nov. 12, 1998).

43. Peevy v. California, 525 U.S. 1042 (1998).

44. 177 F.3d 1152 (9th Cir. 1999), amended by 197 F.3d 1021 (9th Cir. 1999), cert. denied, 528 U.S. $1198(2000)$.

45. See Henry, 197 F.3d at 1025, 1027.

46. Id. at 1028 .

47. Id. at $1027-28$.

48. Id. at 1029 . 
underscoring that the sheriff's deputies "set out in a deliberate course of action to violate Miranda." ${ }^{49}$ The Supreme Court subsequently denied the State's petition for writ of certiorari. ${ }^{50}$

Henry should have sent a strong signal that questioning "outside Miranda" is impermissible and may jeopardize a prosecution. Officers who question over a Miranda invocation run the risk that a court will find any resulting statements involuntary because of the psychological impact of this practice upon a suspect. At the same time, however, because Henry broke down during the interrogation and was told that his statements could not be used against him, some might read the case as a limited holding about false promises and voluntariness.

\section{California Attorneys for Criminal Justice v. Butts}

In 1995, a federal civil rights lawsuit was filed against officers in the Los Angeles and Santa Monica Police Departments, and against those respective cities, seeking to stop police from questioning "outside Miranda." The plaintiffs in California Attorneys for Criminal Justice v. $B u t s^{51}$ were two associations of criminal defense lawyers and two individuals who had been questioned in violation of Miranda and Edwards. Both individual plaintiffs were interrogated after they unequivocally sought counsel. In April 1996, the federal district court dismissed the portion of the case brought by the two bar associations, finding that they lacked standing to seek injunctive relief. ${ }^{52}$ The court permitted the case to go forward on behalf of the two individual plaintiffs, rejecting the defendants' claim that Harris permits officers to question "outside Miranda" to obtain impeachment information. ${ }^{53}$ The case subsequently went to the court of appeals on the officers' interlocutory appeal from the denial of qualified immunity. ${ }^{54}$

49. Id. The court also emphasized that under the California Evidence Code, statements admitted for impeachment are also admitted for the truth of the matters asserted. Id. (citing CAL. EVID. CODE $\$ \$ 1220,1235)$.

50. Kernan v. Henry, 528 U.S. 1198 (2000).

51. 922 F. Supp. 327 (C.D. Cal. 1996).

52. See id. at $330-34$.

53. See id. at 336 ("The impeachment exception was certainly not intended to provide the police with the option of either ceasing questioning or continuing onward in the hopes of acquiring impeachment evidence.").

54. The district court considered cross motions for summary judgment. The court narrowed the case by dismissing the Fourteenth Amendment causes of action, but held that the plaintiffs' Fifth Amendment claims should go to trial. See Order Re: Cross Motions for Summary Judgment Argued August 11, 1997, at 2-5, Cal. Att'ys for Crim. Justice v. Butts (CV 95-8634-ER) (Aug. 26, 1997); Order Granting Defendants' Motion for Summary Adjudication; Denying Plaintiffs' Motion for Certification for Interlocutory Appeal; and Granting Defendants' Request for Stay Pending Appeal on Qualified Immunity Issue at 2-6, Cal. Att'ys for Crim. Justice v. Butts (CV 95-8634-ER) (Oct. 16, 1997). In so ruling, the court reaffirmed its previous denial of qualified immunity to the defendant officers. See Order re: Cross Motions for Summary Judgment, supra, at 5. 
On November 8, 1999, the court of appeals affirmed the denial of qualified immunity. ${ }^{55}$ The court determined that the plaintiffs had alleged constitutional claims. Although "[i]n the narrowest sense" Miranda "is a prophylactic rule, not a constitutional right," Miranda "cannot be viewed entirely apart from the constitutional rights that it protects." Miranda may not be enough to establish a $\S 1983$ action, the two plaintiffs additionally alleged that officers made assurances that the plaintiffs' statements could not be used against them and, in one case, denigrated the role of counsel. ${ }^{57}$ The court also ruled that the constitutional right was clearly established and that reasonable officers should have known that their actions violated the plaintiffs' Miranda rights. ${ }^{58}$ Echoing Peevy, the court expressly rejected the claim that Harris v. New York, Oregon v. Hass and Michigan v. Tucker affirmatively permit officers to question suspects who have invoked their rights: "The Supreme Court has never suggested ... that these decisions dealing with the peripheral use of statements obtained in violation of Miranda somehow overcame Miranda's imperatives concerning proper police procedure." ${ }^{59}$ Finally, and perhaps most significant to officers in California, the circuit found that police could not escape liability by arguing that they relied upon their "outside Miranda" training in good faith. ${ }^{60}$ The court concluded that "[o]fficers who intentionally violate the rights protected by Miranda must expect to have to defend themselves in civil actions."

The officers sought Supreme Court review. The Court denied their petition for a writ of certiorari on June $26,2000,{ }^{62}$ the same day that Dickerson was decided.

55. 195 F.3d 1039 (9th Cir. 1999), cert. denied, 120 S. Ct. 2717 (2000).

56. Id. at 1045.

57. See id. at 1046-48. The court followed an earlier case, Cooper v. Dupnik, 963 F.2d 1220,1244 (9th Cir. 1992) (en banc), where a $\$ 1983$ action was permitted to go forward on behalf of a former suspect who was questioned in violation of Miranda and subjected to abusive tactics. The Cooper court noted that "[t]his case does not establish a cause of action where police officers continue to talk to a suspect after he asserts his rights and where they do so in a benign way." Id. By ruling that the claim should go to trial in Butts, the court determined that the plaintiffs had at least alleged that the questioning "outside Miranda" was not "benign."

58. See Butts, 195 F.3d at 1047.

59. Id. at 1048.

60. See id. at 1049 ("[T] hat Los Angeles and Santa Monica may have trained their police to violate the rights of individuals does not provide any defense for these officers. Their policy contradicts the safeguards provided by Miranda, and, at the very least, is in direct conflict with Cooper [v. Dupnik, 963 F.2d 1220 (9th Cir. 1992) (en banc)].”).

61. Id. at 1050 .

62. Butts v. McNally, 120 S. Ct. 2717 (2000). 
In some respects, Butts is factually similar to Henry: In both cases, officers told the suspects that because they invoked their Miranda rights, their statements could not be used against them. Thus, some might also read Butts narrowly for the proposition that questioning over a Miranda invocation, coupled with false promises, violates the Constitution. But that is not a fair reading of the case. Butts strongly rejects the notion that Harris, Hass and Tucker allow officers to elect to question "outside Miranda." Further, if a simple violation of Miranda is not by itself a Fifth Amendment violation and additional conduct - some sort of "plus" - is needed, Butts and Henry together indicate that that "plus" need not be much. And Butts makes clear that officers who err do so at their personal peril.

\section{Dickerson v. United States}

The tale is by now familiar.

In 1968, Congress enacted the Omnibus Crime Control and Safe Streets Act, a provision of which sought to replace Miranda in federal prosecutions. Under that provision, codified at 18 U.S.C. $\$ 3501$, a voluntary confession "shall be admitted." ${ }^{63}$ The statute also provides that the judge shall consider a variety of factors to determine voluntariness, including whether or not the accused was advised of the right to remain silent and the right to the assistance of counsel. ${ }^{64}$ Though these circumstances are to be taken into consideration, they "need not be conclusive." ${ }^{65}$ In this respect, the statute sought to replace Miranda, which makes its regime of warnings and waiver conclusive, at least as to the admissibility of a statement in the case-in-chief.

The statute lay fallow for years, for the most part unenforced by the Department of Justice and ignored by the courts. ${ }^{66}$ In February

\footnotetext{
63. 18 U.S.C. \& 3501(a) (1995).

64. 18 U.S.C. $\S 3501$ (b) (1995) provides:
}

The trial judge in determining the issue of voluntariness shall take into consideration all the circumstances surrounding the giving of the confession, including (1) the time elapsing between arrest and arraignment of the defendant making the confession, if it was made after arrest and before arraignment, (2) whether such defendant knew the nature of the offense with which he was charged or of which he was suspected at the time of making the confession, (3) whether or not such defendant was advised or knew that he was not required to make any statement and that any such statement could be used against him, (4) whether or not such defendant had been advised prior to questioning of his right to the assistance of counsel; and (5) whether or not such defendant was without the assistance of counsel when questioned and when giving such confession.

The presence or absence of any of the above-mentioned factors to be taken into consideration by the judge need not be conclusive on the issue of voluntariness of the confession.

65. Id.

66. For various accounts of the treatment of the statute, see Paul G. Cassell, The Statute That Time Forgot: 18 U.S.C. $\$ 3501$ and the Overhauling of Miranda, 85 IOWA L. REV. 175, 197-225 (1999); Yale Kamisar, Can (Did) Congress "Overrule" Miranda?, 85 CORNELL L. REV. 883, 925-28 (2000); Michael Edmund O'Neill, Undoing Miranda, 2000 BYU L. REV. $185,233-50$. 
1999, the U.S. Court of Appeals for the Fourth Circuit accepted the invitation of Professor Paul Cassell and the Washington Legal Foundation to resurrect the law in an interlocutory appeal from an order suppressing evidence. The court held that $\S 3501$ was constitutional, and that Charles Dickerson's statement should be admitted into evidence because it was voluntary. ${ }^{67}$ The Supreme Court reversed.

On June 26, 2000, in Dickerson v. United States, ${ }^{68}$ the Supreme Court held by a 7-2 vote "that Miranda, being a constitutional decision of this Court, may not be in effect overruled by an Act of Congress, and we decline to overrule Miranda ourselves." ${ }^{69}$ Writing for the majority, Chief Justice Rehnquist noted the lower court's reliance upon the fact that the Supreme Court had created several exceptions to Miranda's warnings requirement and that the Court had "repeatedly referred to the Miranda warnings as 'prophylactic,'... and 'not themselves rights protected by the Constitution." "70 Conceding "that there is some language in some of our opinions that supports the view," the justices disagreed with the court of appeals' conclusion that Miranda's protections are not constitutionally required. ${ }^{71}$ Addressing the "public safety" and impeachment exceptions described in New York v. Quarles ${ }^{72}$ and Harris v. New York, the majority claimed that " $[\mathrm{t}]$ hese decisions illustrate the principle — not that Miranda is not a constitutional rule - but that no constitutional rule is immutable." J3 Justice Scalia, joined by Justice Thomas, dissented, tearing at the majority for "its carefully couched iterations that 'Miranda is a constitutional decision,' that 'Miranda is constitutionallybased,' [and] that Miranda has 'constitutional underpinnings." "74 According to Justice Scalia, the Court fell short of stating that an unwarned custodial interrogation violates the Constitution "because a majority of the Court does not believe it," perhaps suggesting that the majority was disingenuous in its internal reasoning. ${ }^{75} \mathrm{He}$ accused the Court of engaging in extraconstitutional "power-judging."76

67. See United States v. Dickerson, 166 F.3d 667 (4th Cir. 1999).

68. 120 S. Ct. $2326(2000)$.

69. Id. at 2329.

70. Id. at 2333 (citing New York v. Quarles, 467 U.S. 649, 653 (1984), and Michigan v. Tucker, 417 U.S. 433 (1974)) (footnote omitted).

71. Id.

72. 467 U.S. 649 (1984).

73. Dickerson, $120 \mathrm{~S}$. Ct. at 2335.

74. Id. at 2337 (Scalia, J., dissenting) (citations omitted).

75. Id; see also id. at 2343 (asserting that the Court did not address the claim that Miranda establishes a constitutional prophylactic rule "because, I assume, a majority of the Justices intent on reversing believes that incoherence is the lesser evil").

76. Id. at 2337. 
The dissenters have something of a point: The majority could have held that a violation of Miranda is a per se violation of the Fifth Amendment. But such a ruling would have required the Court to deal more directly with the impeachment and public safety exception cases, which are premised at least in part on the notion that a Miranda violation is not a core constitutional violation. The majority also attempted to distinguish Oregon $v$. Elstad, ${ }^{77}$ which refused to exclude the testimonial fruit of a Miranda violation, claiming that "[o]ur decision in that case ... does not prove that Miranda is a nonconstitutional decision, but simply recognizes the fact that unreasonable searches under the Fourth Amendment are different from unwarned interrogation under the Fifth Amendment."78 This is fairly unsatisfying, inasmuch as the fruits doctrine applies to other types of Fifth Amendment transgressions $^{79}$ and probably to Fourteenth Amendment violations as well, ${ }^{80}$ moreover, the majority in Elstad said that Miranda's exclusionary rule "may be triggered even in the absence of a Fifth Amendment violation." "81 Further, the Court has created a weaker rule of exclusion for statements taken in violation of Miranda than for other types of compelled testimony and for statements that violate the Fourteenth Amendment. ${ }^{82}$ For that reason, concluding that breaches of Miranda

77. 470 U.S. 298 (1985).

78. Dickerson, $120 \mathrm{~S}$. Ct. at 2335.

79. See Kastigar v. United States, 406 U.S. 441, 453 (1972) ("[I]mmunity from use and derivative use is coextensive with the scope of the privilege against self-incrimination, and therefore is sufficient to compel testimony over a claim of privilege.") (emphasis added).

I am not alone in criticizing the Court's clumsy handling of Elstad. See Paul G. Cassell, The Paths Not Taken: The Supreme Court's Failures in Dickerson, 99 MICH. L. REV. 898, 901 (2001); Susan R. Klein, Identifying and (Re)Formulating Prophylactic Rules, Safe Harbors, and Incidental Rights in Constitutional Criminal Procedure, 99 MICH. L. REV. 1030, 1073 (2001); see also Michael C. Dorf \& Barry Friedman, Shared Constitutional Interpretation, 2000 SUP. CT. REV. 61, 80 n.79. Some courts also have had difficulty determining whether Dickerson undermines the holding in Elstad. Compare State v. Walton, No. W1998-00329SC-R11-CD, 2001 Tenn. LEXIS 222, at *37 (Tenn. Mar. 15, 2001) (holding that Dickerson did not overrule Elstad), with People v. Trujillo, No. 98CA2575, 2000 Colo. App. LEXIS 2213, at *5-6 (Colo. Ct. App. Dec. 21, 2000) (ruling that Dickerson distinguished Elstad, and applying the "fruits" doctrine to bar impeachment of defense witnesses).

80. The Supreme Court has apparently never directly faced the question whether the fruits of an involuntary statement must be excluded, though it has come close. In Mincey $v$. Arizona, 437 U.S. 385, 398 (1978), the Court declared that "any criminal trial use against a defendant of his involuntary statement is a denial of due process of law." In Arizona v. Fulminante, 499 U.S. 279, 300 (1991), the Court found that the use of an involuntary statement harmed the defendant for several reasons, including that it made other highlydamaging evidence relevant and, thus, admissible. For a discussion of the reasons why the fruits doctrine should apply to Fourteenth Amendment violations, see Yale Kamisar, On the "Fruits" of Miranda Violations, Coerced Confessions, and Compelled Testimony, $93 \mathrm{MICH}$. L. REV. 929 (1995).

81. Elstad, 470 U.S. at 306.

82. See New Jersey v. Portash, 440 U.S. 450 (1979); Mincey v. Arizona, 437 U.S. 385 (1978). Portash distinguishes Harris and holds that testimony given under a grant of immunity cannot be used for impeachment, because - unlike statements obtained in violation of Miranda - testimony obtained under an order of immunity is truly compelled. See 
are per se Fifth Amendment violations would eventually force the Court to choose among three alternatives: (1) enhance the Miranda exclusionary rule, (2) adopt different exclusionary rules for different types of Fifth Amendment violations, or (3) retreat from earlier holdings that equate Fifth Amendment compulsion with Fourteenth Amendment coercion. ${ }^{83}$ These must have appeared unhappy choices for the Dickerson majority, which also sought to rest its ruling on principles of stare decisis. ${ }^{84}$

Even so, Dickerson should put to rest the claim that Miranda's procedures are merely nonconstitutional suggested guidelines, as hinted in Tucker and as a number of law enforcement instructors have told police. "Congress," the Court held, may "set aside any judicially created rules of evidence and procedure that are not required by the Constitution." 85 That Congress lacked such authority in this case can mean only that Miranda's procedures are indeed required by the Constitution. Further, "[t]he Miranda opinion itself begins by stating that the Court granted certiorari 'to explore some facets of the problems... of applying the privilege against self-incrimination to incustody interrogation, and to give concrete constitutional guidelines for law enforcement agencies and courts to follow." "86 "Concrete constitutional guidelines" are more than mere non-constitutional suggestions. Dickerson's message to law enforcement is that Miranda's rules are here to stay.

Portash, 440 U.S. at 458-59. Similarly, Mincey distinguishes Harris and Hass and holds that the impeachment use of an involuntary statement is a denial of due process. See Mincey, 437 U.S. at 398.

83. If Miranda violations are per se violations of the Fifth Amendment, the Court would have to abandon the Harris/Hass impeachment exception, overturn Portash, or find some other reason for the different outcomes. Likewise, the Court would eventually have to reconcile Tucker and Elstad with Kastigar, and decide whether the "fruits" doctrine applies to Fifth Amendment/Miranda violations as well as to Fifth Amendment/immunity grants. At least one justice has suggested that there is a permissible distinction between the use of "fruits" in these two situations. See New York v. Quarles, 467 U.S. 649, 660, 669-672 (1984) (O'Connor, J., concurring in part and dissenting in part). The Court might also seek to review its earlier rulings equating Fifth and Fourteenth Amendment violations, as some have suggested. See Stephen J. Schulhofer, Reconsidering Miranda, 54 U. CHI. L. REV. 435, 44045 (1987). Yet even if such a review led to different rules of exclusion for Fifth and Fourteenth Amendment violations, the Court would still have to reconcile Harris and Hass with Portash.

84. See Dickerson v. United States, 120 S. Ct. 2326, 2336 (2000).

85. Id. at 2332.

86. Id. at 2333-34 (quoting Miranda v. Arizona, 384 U.S. 436, 441-42 (1966) (emphasis added in Dickerson)). 


\section{Recent Police Training}

\section{A. Uncovering Police Practices}

To assess whether these recent decisions - especially Dickerson - may influence police practices in California, I examined on-the-job ("in-service") law enforcement training materials. Most police officers are not lawyers and they do not usually read legal newspapers; thus, judicial opinions will not have an impact in the stationhouse unless sworn personnel are formally instructed about them. Supporting this view, two studies of police and the Fourth Amendment report that inservice training makes the most significant contribution to officers' understanding of search and seizure law. ${ }^{87}$ Of course, knowledge is not the same as practice. Training materials will not alter police behavior in the stationhouse unless officers decide to follow them. ${ }^{88}$ Training is thus necessary though not sufficient to alter law enforcement behavior.

In late August 2000, I sent formal requests to forty-five law enforcement offices around the state, seeking their training materials on Peevy, Henry, Butts and Dickerson, as well as materials concerning the practice of questioning "outside Miranda." ${ }^{89}$ The requests, made pur-

87. See William C. Heffernan \& Richard W. Lovely, Evaluating the Fourth Amendment Exclusionary Rule: The Problem of Police Compliance with the Law, 24 U. MICH. J.L. REFORM 311, 337-38 (1991) (developing regression model based upon answers to surveys of officers, and finding that extensive in-service training provided the most substantial explanation for officers' understanding of Fourth Amendment law; other dependent variables in the model included college attendance, assignment as supervisor or plain clothes investigator, years of service, number of recent arrests, number of recent suppression hearings, and exposure to law suits); L. Timothy Perrin et al., If It's Broken, Fix It: Moving Beyond the Exclusionary Rule, 83 IOWA L. REV. 669, 730-32 (1998) (surveying officers and reporting that those with continuing training answered $52.6 \%$ of search and seizure hypotheticals correctly, while those without such training answered $35 \%$ correctly; educational background, rank and experience did not necessarily affect performance); see also Corey Fleming Hirokawa, Note, Making the "Law of the Land" the Law on the Street: How Police Academies Teach Evolving Fourth Amendment Law, 49 EMORY L.J. 295, 330-31 (2000) (finding, in a study of Atlanta-area law enforcement agencies, that the complexity of search and seizure law does not appear to have led departments to decrease their efforts to teach procedures that comply with the Fourth Amendment). But see Myron W. Orfield, Jr., Deterrence, Perjury, and the Heater Factor: An Exclusionary Rule in the Chicago Criminal Courts, 63 U. COLO. L. REV. 75, 91-92 (1992) (reporting that, in survey of judges, prosecutors and defense lawyers, $51 \%$ of respondents believe that the experience of having evidence suppressed is at least as effective as teaching officers the law).

88. Heffernan and Lovely also report that, in approximately $15 \%$ of the responses, officers indicated their willingness to search a suspect or a dwelling in deliberate violation of the Fourth Amendment. See Heffernan \& Lovely, supra note 87, at 346-55. In-service training affected the officers' knowledge of the law, but not their willingness to comply with it. See id. at 354-55.

For a fuller discussion of this point, see infra Section III.A.

89. Appendix A to this Article contains a sample request to a police department. For the most part, the same request was sent to each agency, with slight wording changes for district attorney and sheriff's offices. 
suant to the California Public Records Act, ${ }^{90}$ went to the Commission on Peace Officer Standards and Training, the District Attorneys and Sheriffs ${ }^{91}$ in fourteen counties, and the Chiefs of Police in sixteen large cities. ${ }^{92} \mathrm{I}$ included District Attorneys because police often learn about the law from individual prosecutors, even if Deputy District Attorneys and their investigators do not themselves conduct many custodial interrogations. I collected instructional materials from POST, the Attorney General's Office, and statewide organizations. I received responses from ten District Attorneys (71\% response), nine Sheriffs (64\% response), and ten local police departments (62.5\% response). ${ }^{93}$

Section $\mathrm{B}$, infra, describes the training materials issued by POST and other statewide entities. I believe that I have obtained a fairly comprehensive set of materials distributed by state agencies and statewide organizations, and can therefore safely draw conclusions about the effect of Dickerson and other cases upon statewide training. The materials collected from local agencies are less comprehensive. Section C, infra, describes instruction in select counties and cities.

\section{B. Statewide Training}

\section{Commission on Peace Officer Standards and Training}

The Commission on Peace Officer Standards and Training ("POST"), part of the California Department of Justice, is the most active statewide training body for police officers and deputy sheriffs. POST approves standard curricula for new officer instruction, and certifies in-service or advanced officer training. POST also conducts a monthly satellite video broadcast with case law updates, and the broadcast is downloaded by law enforcement agencies across the state. ${ }^{94}$

90. CAL. Gov'T CODE $§ \S 6250-6268$ (1995 \& Supp. 2001).

91. Felonies are generally prosecuted by the county district attorneys' offices. See CAL. Gov’T CODE $\S 26500$ (1988 \& Supp. 2001). The Sheriff's departments are county-wide law enforcement agencies. District attorneys and sheriffs are elected in each county. See CAL. GOV’T CODE $\$ \$ 24000,24009$ (a) (1988 \& Supp. 2001). Most cities in California have their own police departments, each headed by an appointed chief, though some incorporated and all unincorporated areas rely upon the county sheriff for local law enforcement. See CAL. GOV’T CODE $\$ \$ 36501,36505$ (1988 \& Supp. 2001).

92. Appendix B to this Article lists the counties and cities that I surveyed and notes which agencies responded to the Public Records Act requests.

93. See infra Appendix B.

94. The monthly broadcast, formerly titled Case Law Updates, is now called Case Law Today. Each broadcast contains a series of short topics. For a list of broadcasts and topics, see Case Law Today Broadcasts at http://www.post.ca.gov/cptn/casebrod.htm (last visited Mar. 1, 2001). 
It is difficult to overemphasize the impact of POST. Even if many officers in an agency do not see the POST materials directly, they are usually trained by people who do. Moreover, most detectives and investigators - who ordinarily conduct the custodial interrogations in serious cases - have received advanced interrogation training in POST-approved courses. ${ }^{95}$ Many of these courses are provided by trainers outside of the officers' own departments, who may be unfamiliar with local policies and practices. Thus, even if a local law enforcement agency has a policy of strict compliance with Miranda, detectives and other investigators may receive advanced instruction from people operating under a different set of guidelines.

POST's monthly satellite broadcasts have addressed the recent Miranda cases. POST's July 1998 broadcast included a segment on the impeachment exception and Peevy. ${ }^{96}$ The segment reviews Harris, Hass, and Branscombe (the depublished decision) ${ }^{97}$ before turning to Peevy. The trainer, a deputy district attorney, reports that a statement "is perfectly admissible even though the police officer deliberately took it for purposes of impeachment." He then warns that it cannot be used for any purpose if it is rendered involuntary by the interrogator "assuring the person that it will be off the record and cannot be used against them in court." 98 He adds:

Another caution. You see sometimes the newscasters giving you the news and then they want to give you their opinion about that. They want to add something that's not the facts, it's just their commentary. And so down at the bottom of the screen it says, opinion or commentary. When a court does that they call it dicta. They've got their ruling, which might be the news, and then they've got their commentary, which is called dicta. It means this is not binding on anybody. This is not a statement of the law. This is just us expressing our personal opinions about something. In Parts B and C of their opinion in Peevy, the California Supreme Court expressed its displeasure with the tactic of questioning outside Miranda in order to obtain an impeachment statement. They made it very clear

95. According to a POST analyst, over 7,000 POST-approved training courses are offered each year. See Letter from Anna del Porto, Associate Analyst, POST (Oct. 11, 2000) (on file with author). A recent catalog of POST-approved courses runs 263 pages. See COMM'N ON PEACE OfFICER STANDARDS AND TRAINING, POST CATAlog OF CERTIFIED COURSES (Sept. 2000). It lists 17 advanced courses on interrogation and interviews from POST-approved providers (see id. at 174-76), though many other advanced courses also deal with interrogation. The current catalog may be viewed at http://www.post.ca.gov-/catalog/ intro.htm (last visited Mar. 1, 2001).

96. See Videotape: Case Law Updates: Questioning "Outside Miranda" for Impeachment (Golden West College) (POST July 9, 1998) (on file with author) [hereinafter Videotape 1].

97. Branscombe was depublished on June 24,1998 , see supra note 41 , two weeks before the videotape was broadcast. The videotape segment is undated, and may have been produced prior to the order depublishing the decision.

98. Videotape 1, supra note 96. 
they don't approve of it. They thought in their opinion that it was illegal, they said. That's the word that they used, though they were unable to cite to a U.S. Supreme Court case, since there isn't one, saying that it's illegal. The U.S. Supreme Court has consistently said this is an evidentiary rule that will limit use of the statement in court. They have never said it is illegal to question without Miranda compliance. Nor, I will bet my money, will they ever. But the California Supreme Court in its commentary, in its dicta said, this is illegal, it's improper.

So before you decide whether or not you want to go outside Miranda and take an impeachment statement that will be admissible if it's otherwise voluntary, you may want to do what we always caution you to do, seek advice from your departmental legal adviser, local prosecutor, city attorney or county counsel, whoever you turn to for advice. I commend you to their advice. As to the admissibility of the evidence, a statement deliberately taken outside Miranda, if it's otherwise voluntary, is admissible for impeachment, People v. Peevy. You're up-to-date as of now. ${ }^{99}$

POST broadcast another segment after the Fourth Circuit's ruling in Dickerson. ${ }^{100}$ The trainer emphasizes that Miranda establishes a prophylactic rule, not rights protected by the Constitution, and that if Miranda can be preempted by a statute in the federal courts, "it could be done state by state by state."101

After the ruling in Henry $v$. Kernan, POST broadcast a segment warning officers about tactics that may lead to an involuntary statement. ${ }^{102}$ In this segment, the trainer, a different prosecutor than that featured in the two other broadcasts, underscores that repeated Miranda violations may amount to badgering and may prevent a statement from being used for any purpose. In contrast to the earlier broadcasts, he expressly tells officers not to question in violation of Miranda: "It isn't worth it. It isn't worth your reputation or the reputation of your department - much less the potential civil rights liability under 42 U.S. Code 1983 - to willfully violate Miranda."103

Yet another broadcast was issued after the Ninth Circuit's decision in Butts, featuring the same deputy district attorney who appeared in the videos on Peevy and Dickerson. ${ }^{104} \mathrm{He}$ instructs that a Fifth

99. Id.

100. See Videotape: Case Law Updates: Miranda: Beginning to Crumble? (Golden West College) (POST May 6, 1999) (on file with author).

101. Id. He adds that "[T]his could be the beginning of the end of Miranda. I don't want to be too optimistic. ... But the Fourth Circuit says we are on our way on that mission." Id.

102. See Videotape: Case Law Today: Miranda: Ignoring Invocation by Upset Subject Collapses Case (Alameda County Dist. Attorney's Office) (POST Aug. 5, 1999) (on file with author).

103. Id.

104. See Videotape: Case Law Today: Civil Liability “Outside Miranda?" Cal. Att'ys for Crim. Justice v. Butts (Golden West College) (POST Jan. 13, 2000) (on file with author). 
Amendment violation can occur only at trial, and that a bare Miranda violation is not enough to establish civil rights liability under $\S 1983$. He emphasizes that Butts involved allegations of coercive techniques in addition to questioning "outside Miranda," and that is why the officers might be subject to civil rights liability. ${ }^{105}$ The trainer adds:

In Oregon v. Elstad, the U.S. Supreme Court said, point blank, a Miranda violation does not constitute coercion. So how could the Ninth Circuit or anybody else ever come along and say, hmmm, that's enough by itself? They couldn't, they haven't - no matter what you have seen in the press. No matter what you might hear from people who are running around wetting their pants over this thing and saying, oh, the sky is falling, if we have any kind of non-compliance with Miranda we're going to get sued, they are oversimplifying, they are over-reading this case. This case says coercive tactics, which you should never use under any circumstances anyway, combined with questioning outside Miranda, could mean you have to stand trial. Doesn't mean you're liable. Could mean you have to stand trial. You don't get out on summary judgment motion. You don't get out on qualified immunity. Procedural issue.

But all of these cases have said, from the U.S. Supreme Court and even from the Ninth Circuit, they have said, there is no cause of action, there is no constitutional violation where all police are alleged to have done is continue to question somebody after a Miranda invocation. ${ }^{106}$

As of March 2001, POST has not broadcast a segment on the Supreme Court's ruling in Dickerson. ${ }^{107}$

As noted, POST also certifies law enforcement training programs. ${ }^{108}$ In the wake of Dickerson, POST's executive director issued a memorandum to all "POST Certified Training Presenters," emphasizing respect for Miranda and stating that POST's policy is that no officer shall continue to interrogate a suspect over a Miranda invocation. ${ }^{109}$ The director's message, however, was undone by a sentence in the last part of his memorandum: "Procedures related to the impeachment' exception are a matter of local policy and are referred to each independent agency for clarification." 110 It is difficult to predict

105. Id.

106. Id.

107. See POST Case Law Today Broadcasts, available at http://www.post.-ca.gov/cptn/ casebrod.htm.

108. See CAL. PENAL CODE $\$ \S 13510.1,13511.3,13519.9$ (2000).

109. Memorandum from Kenneth J. O'Brien, Executive Director, Commission on Peace Officer Standards and Training to POST Certified Training Presenters 1 (Aug. 14, 2000) (on file with author).

110. Id. The memorandum provides:

Recently the United States Supreme Court ruled that Miranda procedures were a "constitutional rule" and that Congress could not supersede the safeguards established by the court decision legislatively. The Court preserved the defendant's Fifth Amendment protections es- 
how the hundreds of POST-certified trainers will instruct officers in light of this memorandum.

\section{California Attorney General's Office}

The California Department of Justice publishes the California Peace Officers Legal Sourcebook ("the Sourcebook"), which is widely used by prosecutors and police, including many law enforcement trainers. Portions of the Sourcebook were provided by a number of departments that responded to the request for training materials. The Sourcebook contains a section titled "Deliberately Ignoring an Invocation," which has been substantially revised in the wake of Peevy, Butts and Dickerson.

Prior to the Peevy decision, the Sourcebook opined that a voluntary "outside Miranda" statement should be admissible for impeachment, noting that "the Miranda decision is not a code of conduct setting forth how police must conduct their investigations in the field." 11 After Peevy, the section was revised to explain that the California Supreme Court held that evidence taken in deliberate violation of Miranda could be used for impeachment. ${ }^{112}$ The Sourcebook also references the part of the decision that calls such tactics "illegal," but questions this holding and characterizes it as dicta. ${ }^{113}$ This section of the Sourcebook concludes that "[i]t may take a decision from the United States Supreme Court to finally settle this question and resolve the apparent conflict between the dicta in Peevy and federal law."114 Another portion of the Sourcebook emphasizes that "nothing in the

tablished in Miranda. Certified POST curriculum has always included a "respect" for the protections established in the Miranda decision and a prohibition against illegal or improper misconduct. As a result of the recent reaffirmation of the rights established in the Miranda decision, the following points need to be repeated as the Commission's policy:

- No officer shall intentionally violate Miranda by continuing to interrogate a suspect after they have invoked their right to counsel or to remain silent.

- No officer shall engage in any conduct that can be concluded to be "coercive" including making false promises following the invocation of Miranda rights.

Procedures related to the "impeachment" exception are a matter of local policy and are referred to each independent agency for clarification. The POST Commission is committed to compliance with the "spirit" as well as the letter of the Supreme Court's ruling.

Id.

111. SOURCEBOOK, supra note $21, \$ 7.40 \mathrm{a}-\mathrm{b}$ (Rev. Mar. 1997).

112. See SOURCEBOOK, supra note $21, \S 7.40$ a (Rev. July 1998) (on file with author) (noting that an "outside Miranda" statement "may be used to impeach the defendant regardless whether the police non-compliance with Miranda's procedures was negligent (accidental) or intentional"); id. $\$ 7.48 \mathrm{~b}$ ("[I]f you fail to comply with the Miranda guidelines in a non-coercive way, although any statement you obtain will be inadmissible at trial to prove guilt (i.e., in the prosecution's 'case-in-chief'), that is the only 'penalty.' The statement will be admissible in rebuttal to impeach . . .; you can also use the statement for any other purpose.") (citations omitted).

113. See id. $\$ 7.40 \mathrm{~b}$.

114. Id. 
Miranda decision is constitutionally required," noting that "if you fail to comply with the Miranda guidelines in a non-coercive way, although any statement you obtain will be inadmissible at trial to prove guilt (i.e., in the prosecution's 'case-in-chief'), that is the only 'penalty.' "115

Following the Ninth Circuit's decisions in Henry and Butts, the Attorney General's Office began to hedge. The Sourcebook notes that there were coercive aspects to the questioning in those cases but that Henry could also be read to hold that a deliberate violation of Mirand $a$ is itself a violation of the Fifth Amendment. ${ }^{116}$ Further, the Sourcebook remarks that:

[R]eview by the United States Supreme Court will be sought in both Henry and Butts. In the meantime, however, it is understandable that many departments in this state have instructed their officers to strictly comply with Miranda's procedures, at least pending further developments, not the least of which will be the high court's upcoming decision in the Dickerson case. ${ }^{17}$

The ruling in Dickerson and the denials of certiorari in Henry and Butts led the Attorney General's Office to change its training. The Sourcebook was revised to read:

[A] deliberate or intentional violation of Miranda is an extremely risky tactic in California at this time, not so much because of Dickerson, but rather because of the Ninth Circuit, which has ruled that a deliberate Miranda violation, in combination with almost any other or additional conduct which the court also views as "coercive," will:

- render any subsequently obtained statement "coerced," "involuntary" and therefore inadmissible for any purpose, including impeachment; and

- entitle the suspect to sue for a civil rights violation under the Fifth Amendment for which the offending officer(s) can be found personally liable! ${ }^{18}$

Thus, "the 'bottom line' now must be: do not intentionally violate Miranda, in particular, do not ignore an invocation of the right to silence or counsel. This is because an intentional violation will virtually guarantee a civil rights lawsuit against you and your department...."119 Further, following Dickerson, the Sourcebook also stepped away from its earlier teaching that nothing in Miranda is constitutionally required, noting that "a majority of Justices characterized

115. Id. $\$ 7.48 \mathrm{~b}$.

116. SOURCEBOOK, supra note $21, \S 7.40 \mathrm{~b}$ (Rev. Jan. 2000).

117. $I d . \$ 7.40 \mathrm{c}$.

118. SOURCEBOOK, supra note $21, \$ 7.40 c$ (Rev. Sept. 2000) (emphasis in original).

119. Id. $\$ 7.40 \mathrm{~d}$ (emphasis in original); see also id. $\$ 7.86$ (stating that even a noncoercive Miranda violation may result in civil rights liability where it is intentional and done in combination with some other conduct). 
[Miranda's] 'prophylactic' procedures as being 'constitutionally based' and therefore amounting to a 'constitutional rule' (although still clearly not part of the Constitution itself)."

\section{Statewide Organizations}

The California District Attorneys Association ("CDAA") publishes a monthly training bulletin, Did You Know ..., with occasional articles about Miranda. Prior to Peevy, at least one article encouraged officers to question "outside Miranda," noting that "since Miranda is not of constitutional dimension, officers risk no civil liability.... Instead, they have 'little to lose and perhaps something to gain....',"121 After Peevy, Henry and Butts, the bulletin took the opposite tack, printing an article that states that Henry and Butts have blurred the distinction between a Miranda violation and Fifth and Fourteenth Amendment violations, and cautioning that " $[\mathrm{w}] \mathrm{e}$ must remember that courts are uniformly critical of intentional Miranda violations as a law enforcement tactic and that we, as officers of the court, should not be encouraging this practice."122 Following Dickerson, the bulletin has emphasized that Miranda is a constitutional rule, noting,

Except for the increased likelihood of officers being held civilly liable for intentional violations of the Miranda rule - a practice we as prosecutors should be discouraging anyway - Dickerson $v$. United States does not really do much more than dash the hopes of all those who thought Miranda might just go away. Otherwise, courtesy of the Supreme Court, plan on business as usual for the unforeseeable future. ${ }^{123}$

In addition, the CDAA also publishes a treatise on Miranda that is widely distributed to prosecutors. ${ }^{124}$ The treatise contains a comprehensive and straightforward summary of the relevant law, describing the impeachment exception but also the full ruling in Peevy and the

120. Id. \& 7.48a.

121. Devallis Rutledge, Questioning "Outside Miranda," in DID You KNOw ... 1995, at 4 (Cal. Dist. Attorney's Ass'n, DID You KNow. . Series, June 1995) (on file with author) (quoting Cooper v. Dupnik, 963 F.2d 1220, 1244 (9th Cir. 1992), and Oregon v. Hass, 420 U.S. 714, 723 (1975)).

122. Robert C. Phillips, Miranda and the Constitution, in DID You KNOw . . 2000, at 2 (Cal. Dist. Attorney's Ass'n, DID You KNOW. . . Series, Feb. 2000) (on file with author); see also Robert C. Phillips, After a Miranda Invocation: The Interrogator's Options, in DID YOU KNOW . . 2001, at 1 (Cal. Dist. Attorney's Ass'n, DiD You KNOw. . Series, Jan. 2001) (on file with author) (describing other circumstances in which police may permissibly reinitiate interrogation after an invocation, and stating that prosecutors "probably have a professional, if not ethical, duty to discourage law enforcement" from questioning "outside Miranda").

123. Robert C. Phillips, Miranda Lives, in DID YOU KNOW . . 2000, at 3 (California Dist. Attorney's Ass'n, DID You KNOW. . Series, July 2000) (on file with author).

124. Robert C. Phillips, Miranda AND the LAw (1999). 
circumstances that may lead courts to rule that statements are involuntary and inadmissible for all purposes. ${ }^{125}$

The California Peace Officers' Association regularly distributes training bulletins that are collected from agencies throughout California. In August 2000, the Association distributed a bulletin noting that up until the Fall of 1999, officers in California had been instructed that it was appropriate in some cases to question over a Miranda invocation. ${ }^{126}$ The bulletin reviews the Butts and Dickerson decisions and states:

On June 26, 2000, the United States Supreme Court reaffirmed the requirement of Miranda and refused to review the "Butts" case....

Despite good faith differences of opinion, the issue is now settled; police are not permitted to continue questioning suspects who invoke their Fifth Amendment Rights without facing potential personal liability, as well as the inadmissibility of any statements which might be elicited thereafter....

It is now, more than ever, imperative that officers be aware of the United States Supreme Court ruling and know that Miranda Warnings shall be given to custodial suspects prior to interrogation and all questioning shall cease when Miranda Rights are invoked in any fashion, and at any time prior to or during the interrogation. ${ }^{127}$

\section{Local Training}

\section{District Attorneys' Offices}

The county district attorneys' offices vary greatly in their Miranda training. For example, in the wake of the California Supreme Court's ruling in Peevy, the Los Angeles District Attorney's office issued a directive to all prosecutors and investigators, stating: "It is the policy of this office that deputy district attorneys shall not advise any law enforcement officer to continue to ask questions for the purpose of obtaining "impeachment" evidence after a suspect has invoked his Miranda rights." ${ }^{128}$ By contrast, a bulletin prepared by a leading trainer in the Orange County District Attorney's Office reports that statements taken in deliberate violation of Miranda are admissible for

125. See id. at 144-48, 163-68.

126. See Cal. Peace Officers' Ass'n, Training Bull. Serv., Miranda Update QUESTIONING "OUTSIDE" MIRANDA 1 (Aug. 2000) (on file with author). "Fall of 1999" most likely refers to the ruling in Butts.

127. Id. (emphases in original).

128. Special Directive 98-02 from Robert P. Heflin, Chief Deputy District Attorney, to All Deputy District Attorneys and All District Attorney Investigators 1 (June 18, 1998) (on file with author) (original language in bold). 
impeachment. ${ }^{129}$ The author opines that the result should be the same even if there were to be a proven policy of non-compliance with Miranda. ${ }^{130}$ Obliquely referring to the portion of the Peevy opinion that calls such tactics "illegal" and "misconduct," the newsletter concludes:

In what a constitutional scholar from the Criminal Justice Legal Foundation has charitably described as "unfortunate dictum," the Peevy court delivered itself of some additional statements of its understanding of the nature of Miranda ... that will be open to serious dispute if they should ever form the basis of a ruling. Meanwhile, like they say down home, "If you've caught the fish, don't fret about losing the bait."131

The training materials produced by the different county prosecutors are not easily categorized. The responses to the Public Records Act requests leave the overall impression that many county prosecutors have been quicker and more certain than their statewide counterparts in cautioning against questioning "outside Miranda," but instruction is not uniform among counties and, indeed, may not be consistent even within a single given county.

Two counties, Alameda and San Diego, have promulgated particularly extensive training materials, which appear to be widely distributed both inside and outside of those counties. It is worth describing their training documents in detail.

a. Alameda County. ${ }^{132}$ The Alameda County District Attorney's Office produces several sets of in-house training materials. It publishes written case updates four times a year, called Point of View. It has also, until recently, produced videotapes with case updates, also called Point of View. ${ }^{133}$ In addition, the Office publishes a manual, California Criminal Investigation.

The written Point of View series has occasionally discussed questioning following a Miranda invocation. A 1993 article addresses the admissibility of statements taken in violation of Miranda, but does not encourage such questioning. ${ }^{134}$ Later, the California Supreme Court's

129. See Orange County Dist. AtTorney, Good to KNOW ..., IMPEACHMENT WITH POST-INVOCATION STATEMENTS 1-2 (May 1998) (on file with author). The same trainer appeared in the POST videotapes following the Peevy and Butts decisions.

130. See id. at 2 .

131. Id. (original in brackets).

132. Alameda is a large, urban county in northern California that includes the City of Oakland. The population of Alameda County and Oakland as of April 2000 are 1,443,741 and 399,484 , respectively. The population data are from the U.S. Census Bureau and are available at http://factfinder.census.gov (last visited Apr. 20, 2001).

133. The videotapes are distributed to police agencies; Alameda County prosecutors do not watch them. E-mail from William M. Baldwin, Assistant District Attorney to Charles D. Weisselberg (Aug. 28, 2000) (on file with author).

134. See Alameda County Dist. AtTorney's OfFice, Point of View, The Law of Police Interrogation; Miranda: Part Two, at 15-16 (Spring 1993) [hereinafter PóINT OF VIEW] 
ruling in Peevy was summarized in Point of View, emphasizing the connection between Miranda violations and involuntariness and noting that statements may be excluded for all purposes if taken pursuant to a policy of intentionally violating Miranda, but not discussing the portion of the decision that labels questioning "outside Miranda" "illegal" and "misconduct."135 After the Ninth Circuit ruled in Henry $v$. Kernan, an article again stresses that "outside Miranda" questioning may make a statement involuntary. ${ }^{136}$ Following the ruling in Butts, Point of View extensively discusses the case and concludes: "In light of this decision and others that have preceded it, there is only one thing to say about 'going outside Miranda': DON'T." 137 Most recently, according to the District Attorney's Office, "Dickerson should put an end ..." to questioning "outside Miranda" because the ruling rejects the claim "that Miranda was nothing more than a 'recommended procedure,' and was not a Constitutional requirement."138

The Point of View videotapes, which are distributed to law enforcement agencies within the county, appear more receptive to the tactic of questioning "outside Miranda," at least up until the time of the Ninth Circuit's decision in Butts. A videotape on Peevy tells officers that a statement taken in deliberate violation of Miranda is admissible for impeachment, but does not describe Peevy's condemnation of such questioning. ${ }^{139}$ Another videotape describes the holding in Branscombe, a case that was depublished two months before the video was produced. ${ }^{140}$ That videotape mildly encourages officers to question over a Miranda invocation, noting that even if a statement will have only a limited use at trial, it "puts us in a better position" because

(on file with author).

135. See POINT OF VIEW, supra note 134, People v. Bey, at 22 (Spring 1994) (on file with author) ("It should come as no surprise that the courts are not going to sit by and watch as officers conduct custodial interrogations 'outside Miranda'.... We had hoped this issue had been put to rest in 1991 when the Court of Appeal published its decision in [another "outside Miranda" case]."); see also POINT of VIEW, supra note 134, People v. Peevy, at 16 (Summer 1998) (on file with author) (indicating disapproval of the practice).

136. See POINT OF VIEW, supra note 134, Henry v. Kernan, at 31-32 (Summer 1999) (on file with author). The article ends with this noncommittal comment: "Eventually, the legality of 'going outside Miranda' will have to be decided by the United States Supreme Court. The sooner, the better." $I d$. at 32 .

137. See POINT OF VIEW, supra note 134, McNally v. Butts et al. [sic], at 21 (Winter 2000) (on file with author).

138. Dickerson v. United States, POINT OF VIEw ONLINE, available at http://www.co.alameda.ca.us/da/pov/dickerson_2.htm (last visited Mar. 1, 2001).

139. Videotape: Point of View: Evading Miranda; Peevy (Alameda County Dist. Attorney's Office, July 7, 1998) (on file with author). The trainer points out that Miranda is not a constitutional rule, but officers should not throw away their Miranda cards. Id.

140. See Videotape: Point of View: Investigation: Beyond Miranda (Alameda County Dist. Attorney's Office, Aug. 24, 1998) (on file with author). 
"[w]e can use it to impeach, which means to disrupt their case."141 Following the ruling in Henry $v$. Kernan, another videotape tells officers that "[y]ou can get stuff to impeach and it is admissible" if voluntary. ${ }^{142}$ But, the trainer warns, "[D]on't push it. We're being given a little bit of leeway here." 143 The instruction after Butts is markedly different. A new trainer notes that he has seen written manuals that "have told officers that it's perfectly all right to ignore an unambiguous Miranda invocation" and "it's hard to understand with the courts coming down as they have on these cases why it's still going on." $144 \mathrm{He}$ tells police, unambiguously, that "[a]s far as outside Miranda goes, don't do it." 145

The Alameda County District Attorney's Office investigation manual, California Criminal Investigation, expressly instructs that once a custodial suspect invokes his right to silence or his right to counsel, officers must terminate the interrogation. ${ }^{146}$ Following the decision in Dickerson, the manual was revised to state that questioning "outside Miranda" is "[p]robably illegal," and that Dickerson has rejected the theory that underlies the practice. ${ }^{147}$ The manual also now cites Butts and notes that officers who question "outside Miranda" may be sued. ${ }^{148}$

b. San Diego County. ${ }^{149}$ The CDAA treatise, authored by a San Diego deputy district attorney, ${ }^{150}$ is the main reference for prosecutors in the office. ${ }^{151}$ More recent training for prosecutors reviews Butts,

141. Id. Further, "if the defendant takes the stand, we may then take these statements obtained by going beyond Miranda, not as a result of coercion, but simply going beyond the original Miranda concept that we all had and we're now learning is wrong, to keep him from getting away with perjury." Id.

142. Videotape: Point of View: The Limits of "Beyond Miranda; Henry v. Kernman [sic] (Alameda County Dist. Attorney's Office, June 15, 1999) (on file with author).

143. Id.

144. See Videotape: Point of View: Beyond Miranda Back in Court (Alameda County Dist. Attorney's Office, Dec. 6, 1999) (on file with author).

145. Id.

146. See Alameda County Dist. Attorney's Office, California Criminal INVESTIGATION 197 (2000) (on file with author).

147. Alameda COUNTY Dist. ATtorney's OfFiCE, California CRIMinal INVESTIGATION - INTERNET UPDATE, available at http://www.co.alameda.ca.us/da/cci/ -confessions_24.htm (last visited Sept. 2000).

148. Id.

149. San Diego is large county in southern California with both urban and rural areas. It includes the Cities of San Diego and Oceanside. The populations of San Diego County and the Cities of San Diego and Oceanside as of April 2000 are 2,813,833, 1,223,400, and 161,029, respectively. The population data are from the U.S. Census Bureau and are available at http://factfinder.census.gov (last visited Apr. 20, 2001).

150. RoberT C. PHILliPS, MIRANDA AND THE LAW (1999).

151. Telephone Conversation with Craig Rooten, Deputy District Attorney, San Diego County (Sept. 8, 2000). 
Henry and Dickerson at length and states that prosecutors should not advise officers to violate either the Constitution or the dictates of the state and federal courts. ${ }^{152}$ The training outline provides that Dickerson is a reaffirmation of Miranda, "with the possible exception of an increased likelihood of civil liability for police officers (and prosecutors who advise intentional violations)."153

The District Attorney's Office regularly publishes a legal update for law enforcement agencies within San Diego County. ${ }^{154}$ The issue after Peevy reviews the holding, and also acknowledges that the Court found that officers have an affirmative duty to cease questioning upon an invocation. ${ }^{155}$ The update states that "[l]aw enforcement agencies should not be teaching or encouraging a 'systematic policy' of violating Miranda." 156 The publication tells police about the circuit court ruling in Dickerson, advising that it has no direct effect here but may foreshadow change. ${ }^{157}$ The publication is critical of the ruling in Henry, arguing that the court improperly determined that a calculated plan to violate Miranda violates the Constitution. ${ }^{158}$ Following Butts, the District Attorney's Office noted that local law enforcement agencies are being encouraged by legal advisors to issue a directive not to question over an invocation. That directive is "overly broad" because officers can question over an invocation where several established exceptions apply. ${ }^{159}$ At the same time, the update provides that:

[U]nless you're working within one of the recognized exceptions to the Miranda requirement (e.g. "public safety exception" or "rescue doctrine," etc.), do not purposely violate Miranda. Although neither the U.S. nor the California Supreme Court has ever held that an intentional Miranda violation by itself implicates the Constitution, the U.S. Supreme Court has told us not to do it and the California Supreme Court, in Peevy... has referred to it as "illegal." And you can bet your

152. See Robert C. Phillips, Miranda: An Update 3-7 (Oct. 9, 2000) (unpublished manuscript, on file with author).

153. Id. at 15.

154. In addition to the office's formal legal updates, some individual prosecutors working with specific law enforcement agencies have distributed their own bulletins. See, e.g., David J. Lattuca, Legal Update 1 (Nov. 1999) (on file with author) (discussing Butts); David J. Lattuca, Legal Update 1-2 (May 1998) (on file with author) (discussing Peevy).

155. See SAN Diego Dist. ATtORnEy's OfFice, D.A. Liaison Legal UPdATE, Miranda, at 3 (May 1998), available at http://www.clew.org/legalupdate (last visited Mar. 1, 2001) [hereinafter D.A. LIAISON LEGAL UPDATE].

156. Id. at 4.

157. See D.A. LIAison Legal UPdATE, supra note 155, Case Law: Miranda, at 1-2 (April 1999). 1999).

158. See D.A. LIAISON LEGAL UPDATE, supra note 155, Case Law: Miranda, at 5 (Oct.

159. See D.A. LIAISON LEGAL UPDATE, supra note 155, Administrative Notes: Miranda and Civil Liability, at 1 (Nov. 1999). 
boots the Ninth Circuit Court of Appeal will somehow torture the facts to find some way to hold you liable. ${ }^{160}$

After the Court decided Dickerson, officers were told that Miranda imposes a constitutional requirement. ${ }^{161}$ "However," the publication adds, "... contrary to the fears of some, this case does not do much more than create potential civil liability for intentional Miranda violations; something the Ninth Circuit Court of Appeal has been trying to warn us about for some time anyway." 162

\section{Sheriffs and Police Departments}

County sheriffs' offices and city police departments are influenced by outside training materials. In response to the Public Records Act requests, many local law enforcement agencies disclosed or referred to statewide training materials (such as the Sourcebook or POST videos) as well as bulletins issued by district attorneys' offices. Training officers sometimes distribute these items directly to police. Sometimes they use them to create their own documents. Thus, even when detectives and patrol officers receive inservice instruction from trainers within their own departments, outside training materials are quite influential. And many departments send their officers to outside courses, thereby relinquishing control over the content of their officers' training.

Because the statewide instruction is not consistent, police departments that make use of these materials may fail to provide clear guidance to their officers. As an example, one police department in San Diego County gives the district attorney's legal updates to officers, but also requires them to view the POST videos. ${ }^{163}$ The legal updates are much more critical of questioning "outside Miranda" than the POST videos; thus, officers trained with both would not hear a consistent message.

Moreover, as already noted, detectives and investigators routinely attend advanced programs on interrogation and other topics that are conducted outside of their respective agencies. These programs may instruct on tactics that are contrary to the policies of the officers' home departments. This is illustrated by a broadcast issued by the Los Angeles County Sheriff to all deputies, pre-dating Peevy, stating,

160. Id. at $3-4$. 2000).

161. See D.A. LiAiSON Legal UPDATE, supra note 155, Case Law: Miranda, at 3 (July

162. Id. at 4 .

163. Copies of the updates as well as the POST videos were produced by the Oceanside Police Department in response to the Public Records Act Request. See also E-mail from Sgt. Tom Bussey, Oceanside Police Dep't, to Charles D. Weisselberg (Oct. 17, 2000) (on file with author). 
It has come to my attention that training provided by sources outside the department may have caused some deputies to believe that it is appropriate to continue to question a suspect in custody following an invocation of his or her rights under Miranda v. Arizona. . . .

$[\mathrm{M}]$ embers of this department are expected to give Miranda warnings to a suspect prior to a custodial interrogation, and are expected to terminate that interrogation when a suspect invokes his or her rights. ${ }^{164}$

As an additional example of an agency's lack of control over out-ofhouse training, a law firm responding to the Public Records Act request on behalf of the Riverside Sheriff's Department wrote that:

The sources utilized by a law enforcement agency are too numerous to list or provide, and in most instances, the materials are not the property of the Riverside Sheriff's Department. In many instances, officers take classes at P.O.S.T. approved schools, learning from a P.O.S.T. approved curriculum, and the Department is not in possession of the course material. ${ }^{165}$

A number of county sheriffs and police chiefs have now issued formal directives, telling their officers not to question "outside Miranda." Some of these directives have come at the urging of private law firms that represent municipalities and are concerned about civil rights liability. ${ }^{166}$ The orders from agency heads are different in kind from in-service training, for they fix the formal policies of the agencies and - because such directives are issued infrequently - they signal the importance of their message. Given the inconsistent training on Miranda in California, sheriffs and police chiefs may issue orders simply to clarify the duty of officers within the agency. In light of the recent cases, however, the directives may have at least two other aims. Peevy left open the argument that statements taken pursuant to a policy to violate Miranda should be suppressed for all purposes. ${ }^{167}$ Thus, county sheriffs and city police chiefs may issue directives to attempt to defeat claims that evidence should be suppressed for all purposes. And, of course, under Monell $v$. Department of Social Services, ${ }^{168} \mathrm{mu}-$ nicipalities may be subject to civil rights liability for having a custom

164. Department Broadcast from Sherman Block, Sheriff, Los Angeles County, to All Personnel 1-2 (Jan. 29, 1998) (on file with author).

165. Letter from Diana L. Field, Ferguson, Praet \& Sherman, to Charles D. Weisselberg 2 (Sept. 27, 2000) (on file with author).

166. See, e.g., Client Alert Memorandum from Martin J. Mayer, Mayer \& Coble, to All Police Chiefs and Sheriffs (June 30, 2000) (on file with author); Memorandum from Bruce D. Praet, Ferguson, Praet \& Sherman, to All Chiefs and Sheriffs (June 29, 2000) (on file with author); Client Alert Memorandum from Paul R. Coble, Mayer \& Coble, to All Police Chiefs and Sheriffs (Nov. 17, 1999) (on file with author).

167. See People v. Peevy, 953 P.2d 1212, 1225-28 (Cal. 1998).

168. 436 U.S. 658 (1978). 
or policy that deprives individuals of their civil rights. Directives might be issued to avoid municipal liability. ${ }^{169}$

Of the twenty sheriffs' and police departments from which I have obtained materials, ${ }^{170}$ eleven have issued formal directives telling officers not to question "outside Miranda." 171 The timing of these directives is revealing. Table 1 , below, summarizes the dates of the first formal order issued by each department in relation to the recent Miranda decisions. Butts appears to have had the greatest influence upon the agencies that have decided to issue formal directives, though in addition to the directives reflected in Table 1, several agencies have issued orders or specific training bulletins after Dickerson and the denial of certiorari in Butts to reconfirm their earlier orders. ${ }^{172}$

169. For a discussion of the issuance of policies by police departments in the wake of

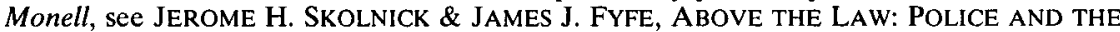
EXCESSIVE USE OF FORCE 201-05 (1993).

170. Nineteen out of thirty sheriffs' and police departments responded to the Public Records Act requests. See infra Appendix B. The Los Angeles Police Department did not respond, but I have obtained materials from that department through other sources.

171. The sheriffs issuing such directives represent the counties of San Bernardino, see Interoffice Memorandum from Gary S. Penrod, Sheriff, San Bernardino County, to All Station/Division Commanders (July 26, 2000) (on file with author); Notice: Interrogations "Outside" Miranda from Gary S. Penrod to All Personnel (undated) (on file with author); Shasta, see SHASTA COUNTY SHERIFF's DEP'T, Training Bull. 2000-04, Miranda Update (July 2000) (on file with author); Riverside, see Departmental Directive \# 00-019 from Larry D. Smith, Sheriff, Riverside County, to All Personnel (July 5, 2000) (on file with author); Fresno, see Fresno COUNTY SHERIFF's DEP'T, ROLl CALl TRAINING BULl., Ninth Circuit Prohibition of Interrogations "Outside Miranda" (Mar. 29, 2000); and Los Angeles, see Department Broadcast, supra note 164.

The police chiefs issuing the directives were of the cities of Stockton, see Special Order No. 00-S-160 from Edward J. Chavez, Chief, Stockton Police Dep't, to All Personnel (Sept. 6,2000 ) (on file with author); Redding, see General Order A-53 from Robert P. Blankenship, Chief of Police, Redding Police Dep't, to All Personnel (July 31, 2000) (on file with author); San Jose, see Memorandum from William M. Lansdowne, Chief of Police, San Jose Police Dep't, to All Sworn Personnel (Dec. 15, 1999) (on file with author); Bakersfield, see Bakersfield Police DeP'T, TRAining Bull., Ninth Circuit Court Prohibition of Interrogations "Outside Miranda" (Dec. 1999) (on file with author); Los Angeles, see Notice 3.3.1 from Bernard C. Parks, Chief of Police, Los Angeles Police Dep't, to All Sworn Personnel (Dec. 2, 1999) (on file with author); and Riverside, see General Order No. 99-15 from Gerald L. Carroll, Chief of Police, Riverside Police Dep't, to All Personnel (Nov. 15, 1999) (on file with author).

I have included the training bulletins from the Fresno and Shasta Sheriffs' Departments on this list even though they are not, per se, directives from the counties' sheriffs, but are rather from others within the sheriff's departments. The bulletins are phrased in sufficiently clear and mandatory language that they would be taken as orders by the sheriffs' deputies. I have excluded a bulletin from the San Francisco District Attorney to the San Francisco Police Department, which asks that officers be advised to stop questioning upon an invocation. See Memorandum from District Attorney Terence Hallinan to Police Legal Affairs (July 17, 2000) (on file with author). The bulletin was distributed to investigators and possibly others in the police department, but is not viewed as a directive from the department itself. Telephone Conversation with Lt. Henry C. Hunter, San Francisco Police Dep't (Oct. 31, 2000).

172. See, e.g., LOS ANGELES COUNTY SHERIFF's DEP'T, FIELD OPERATIONS SUPPORT ServS., Newsletter No. 156, Miranda Warnings, at 1 (Re-released Sept. 2000) (on file with author); BAKERSFIELD POLICE DEP'T, TRAINING BULl., Ninth Circuit Court 


\section{TABle 1: Timing of AgenCy DiRECTIVES, INSTRUCTING OFFICERS NOT TO QUESTION "OUTSIDE MIRANDA"}

\begin{tabular}{|l|l|}
\hline Prior to Peevy & 1 \\
\hline After Peevy & 0 \\
\hline After Henry & 0 \\
\hline After Butts & 7 \\
\hline After Dickerson & 3 \\
\hline Total & 11 \\
\hline
\end{tabular}

The departments that have not issued directives to officers offer a variety of reasons. Some have provided recent in-service training, ${ }^{174}$ and may believe that that instruction will suffice. Others indicate that they have never trained officers to question "outside Miranda" and thus do not need to issue specific instructions to discontinue the practice. ${ }^{175}$

Prohibition of Interrogations "Outside Miranda" - Decision Affirmed (July 2000) (on file with author); Internal Communication from Sgt. Chuck Lebak, City of Redding, to All Sworn Personnel (July 26, 2000) (on file with author); see also Memorandum from District Attorney Terence Hallinan to Police Legal Affairs, supra note 171 (characterizing Dickerson as settling unequivocally whether questioning "outside Miranda" is permissible, and asking San Francisco Police Department to advise officers not to interrogate over an invocation); Special Order No. 00-S-160 from Edward J. Chavez, Chief, Stockton Police Dep't, to All Personnel, supra note 171 (noting that "the U.S. Supreme Court reaffirmed the Miranda decision in a Virginia case, and let stand a California case that said officers could be personally liable for deliberately trampling Miranda rights").

173. The Public Records Act requests sought all training bulletins and materials referring to the practice of questioning "outside Miranda," regardless of date. See infra Appendix A. This should have elicited any orders pre-dating Peevy. Only the Los Angeles County Sheriff produced any directive telling officers not to question "outside Miranda" prior to the decision in Peevy, doing so in January, 1998. See supra note 164 and accompanying text.

174. E.g., Telephone Conversation with Lt. Henry C. Hunter, San Francisco Police Dep't (Oct. 31, 2000) (investigators will shortly be trained on Dickerson); Telephone Conversation with Lt. Casey Nice, Alameda County Sheriff's Office (Sept. 19, 2000) (deputies received roll-call training on Dickerson and have always been trained that questioning "outside Miranda" is risky); Letter from Carol A. Trujillo, Deputy City Attorney, San Diego, to Charles D. Weisselberg (Sept. 12, 2000) (on file with author) (officers receive monthly legal updates from the district attorney's office).

175. E.g., Letter from Matthew Etcheverry, Litigation Unit, Kern County Sheriff's Dep't, to Charles D. Weisselberg (Oct. 5, 2000) (on file with author) (department relies upon POST's Learning Domain 16, and does "not deviate from, nor embellish this area of the law"); Letter from Lt. Ernie Smedlund, Santa Clara Sheriff's Dep't, to Charles D. Weisselberg (Aug. 29, 2000) (on file with author) (training has been not to question suspects "outside Miranda" and so "our practice has remained the same as it was prior to the Peevy decision"); Telephone Conversation with Sgt. Jeff Israel, Oakland Police Dep't. (Aug. 24, 2000) (Peevy, Henry, Butts and Dickerson have not affected training because the department has not trained officers to question "outside Miranda"). 


\section{Summary}

Though statewide training is not uniform, it has generally changed in the wake of the recent Miranda decisions. After the Ninth Circuit's rulings in Henry and Butts, both POST and the Attorney General's Office softened their positions. POST issued seemingly contradictory videotapes: one tells officers not to question in violation of Miranda; the other reports on Butts and gives the decision a narrow interpretation, implying that it is permissible for officers to question "outside Miranda" so long as they do so carefully. POST has not broadcast any videos on the Supreme Court's opinion in Dickerson, though it reported the Fourth Circuit's ruling. After the Supreme Court decided Dickerson (and denied certiorari in Butts), however, the written training from POST, the Attorney General and law enforcement organizations has generally come to counsel adherence to Miranda, with a potentially enormous hiccup: POST has told instructors that impeachment exception "procedures" are a matter of local policy. Future researchers may wish to study the impact of POST's equivocation upon law enforcement officers in California.

There are significant differences at the county and local level as well. Some law enforcement agencies have directed officers not to question "outside Miranda." Other agencies may teach police about the recent decisions or simply expect officers to learn about the rulings in off-site courses.

One of the most striking aspects of the training materials is simply how little changed after the California Supreme Court declared in Peevy that questioning "outside Miranda" is "illegal" and "misconduct" and that Miranda and Edwards impose affirmative duties upon officers. POST and the Attorney General's Office acknowledged but failed to respect the justices' ruling. Neither agency made any effort to halt the practice of questioning "outside Miranda." County prosecutors have seemed more willing to instruct their staff and local police to follow Peevy and not question in violation of Miranda. With respect to county sheriffs and local police, apart from one exception, ${ }^{176}$ local agencies did not appear to direct officers to cease questioning "outside Miranda" until after the Ninth Circuit held in Butts that police officers "who intentionally violate the rights protected by Miranda must expect to have to defend themselves in civil actions." ${ }^{177}$ The ruling in Dickerson seems to have reaffirmed this new instruction by undercut-

176. The one exception is the Los Angeles County Sheriff's Department. See supra note 164 and accompanying text.

177. Cal. Att'ys for Crim. Justice v. Butts, 195 F.3d 1039, 1050 (9th Cir. 1999). The sample of county sheriffs and police departments is, however, quite small and it is difficult to state this result as more than one researcher's impression. 
ting any argument that Miranda's procedures are nonconstitutional and merely optional.

There are several troubling explanations for the general malaise after Peevy. One is that law enforcement officials felt free to disregard Peevy's normative statements because they were not backed with significant sanctions. Another is that law enforcement officials disagreed with the opinion and were simply waiting for a final ruling from the United States Supreme Court. ${ }^{178}$ The second explanation is disturbing because Peevy is a decision from the state's highest court, which routinely decides constitutional questions. If officials disagreed with the ruling, they could have counseled officers to adhere to Miranda and Peevy pending a decision from the U.S. Supreme Court. By and large, however, officials cited the portion of Peevy that advantaged police and ignored the part of Peevy that did not. ${ }^{179}$ Nor did officials issue new training materials after the Supreme Court denied certiorari in Peevy.

Finally, another striking aspect of the training materials is simply that they vary so much. Perhaps this should not be surprising. County district attorneys and sheriffs are elected. Police chiefs are appointed by local officials. Trainers are, in turn, selected by managers within their respective law enforcement agencies. The culture of each agency may vary depending upon such factors as leadership from the top, custom, local crime rates, law enforcement identity with the community and resources. The variance in training appears to be a function of lo-

178. In February 2001, my students and I filed a brief in the California Supreme Court in a case with a Miranda issue. We pointed out that many law enforcement officials did not change their training in the wake of Peevy. See Brief of California Attorneys for Criminal Justice, As Amicus Curiae, Supporting Petitioner, at 13-15, People v. Storm (No. S088712) (Cal. Sup. Ct.) (filed Feb. 1, 2001). In response, the State Attorney General argued that "[w]hile this Court's decision in Peevy clearly foreshadowed the United States Supreme Court's decision in Dickerson ..., which held that Miranda and its progeny were constitutional rules, as opposed to mere rules of evidence, Proposition 8 necessitated guidance from the United States Supreme Court before Miranda and its progeny could be viewed as constitutionally based." People's Answer to Amicus Brief in Support of Appellant, at 2, People v. Storm (No. S088712) (Cal. Sup. Ct.) (filed Mar. 23, 2001). Proposition 8 is a California initiative passed in 1982. It added a new section to the state constitution providing that "relevant evidence shall not be excluded in any criminal proceeding." See CAL. ConsT., art. I, $\$ 28(\mathrm{~d})$. A later initiative, Proposition 115, which passed in 1990, amended the California Constitution to provide that state courts should not construe the State Constitution to afford greater rights than the federal Constitution. See CAL. CONST., art. I, $\$ 24$. While these sections might require a state court to analyze federal constitutional law, neither section provides that a state court's construction of federal constitutional law should not be authoritative or binding within California.

179. The apparent lack of respect for the state court's ruling on issues of federal law is particularly disconcerting because it comes at a time when Congress has decided to require federal courts to defer to state court rulings on issues of federal law that disfavor habeas corpus petitioners. See 28 U.S.C.A. $\$ 2254$ (d) (1) (West Supp. 2000) (habeas corpus relief shall not be granted unless the state court's adjudication of the claim "resulted in a decision that was contrary to, or involved an unreasonable application of, clearly established Federal law, as determined by the Supreme Court of the United States"). 
cal culture, as well as the energy, creativity and personality of particular trainers. The difference among trainers and jurisdictions sharply contrasts with the justices' perceptions of Miranda and Edwards. The Supreme Court is fond of stating that a primary virtue of Miranda and Edwards is their clarity and certainty. ${ }^{180}$ The next part of this Article discusses whether Dickerson and the other recent Miranda decisions may make this assertion true.

\section{The StAtionhouse AFTER DICKERSON}

\section{A. Exclusionary Rules, Hortatory Statements and the Culture of Police}

The Supreme Court's ruling in Dickerson has given Miranda a firm, constitutional footing, but has not - at least yet - altered the contours of Miranda's exclusionary rule. Statements taken in violation of Miranda may still be used for impeachment. Fruits of a Miranda violation are still admissible. The public safety exception remains intact. Within the confines of the criminal case, so long as police do not take an involuntary statement, officers still have "little to lose and perhaps something to gain" by violating Miranda. ${ }^{181}$ We have seen that police training in California is generally shifting to encourage officers to comply with Miranda. But we must then ask whether officers will follow their new instructions and actually change what they do in the stationhouse.

For decades, scholars have debated the virtues and vices of shaping police behavior through exclusionary rules. In an insightful recent article, Sharon Davies approaches the issue from another perspective. Davies explains that an exclusionary rule may, in theory, represent either a "price" - a penalty that permits an officer to choose to cause harm provided that she internalizes the costs - or a "sanction" - a penalty that is attached to conduct that society considers morally wrong and seeks to prevent. ${ }^{182}$ Some of the training materials that encourage police to question "outside Miranda" expressly characterize Miranda's exclusionary rule as a value-neutral pricing scheme. ${ }^{183}$ This

180. See, e.g., Minnick v. Mississippi, 498 U.S. 146, 151 (1990) ("The merit of the Edwards decision lies in the clarity of its command and the certainty of its application."); Arizona v. Roberson, 486 U.S. 675, 681 (1988) ("We have repeatedly emphasized the virtues of a bright-line rule in cases following Edwards as well as Miranda."); Fare v. Michael C., 442 U.S. 707, 718 (1979) ("Whatever the defects, if any, of [the] relatively rigid requirement that interrogation must cease upon the accused's request for an attorney, Miranda's holding has the virtue of informing police and prosecutors with specificity as to what they may do in conducting custodial interrogation....").

181. See supra note 121 and accompanying text.

182. Sharon L. Davies, The Penalty of Exclusion - A Price or Sanction?, 73 S. CAL. L. REV. 1275, 1277-79 (2000).

183. Under this view, there is nothing inherently wrong with questioning "outside 
characterization matters because sanctions establish normative goals and generally also provide greater incentives for compliance, assuming that the legal obligation is enforced by a reasonable penalty. ${ }^{184}$

Davies argues that Miranda's exclusionary rule is most properly seen as a sanction and not a price, ${ }^{185}$ and this seems correct after Dickerson and the other recent Miranda decisions. Even if officers are trained about these decisions, however, Miranda's exclusionary rule still provides few incentives for law enforcement compliance. Peevy holds that deliberate, pre-meditated violations of Miranda and Edwards may nevertheless yield statements that can be used for impeachment. Assuming that Dickerson and the other recent decisions firmly reject the notion that Miranda and Edwards represent mere value-neutral rules of evidence, and that Miranda's exclusionary rule is a sanction not a price, the question remains whether the moral force of these rulings can carry the day in the stationhouse. ${ }^{186}$ There may be particular reason for skepticism, inasmuch as the hortatory language in Peevy went mostly unheeded. The incentive to bring real change in the stationhouse must stem from a force other than Miranda's exclusionary rule or judicial declarations about the legitimacy of Miranda, even after Dickerson.

One possibility is that officers may be induced to follow Miranda by the fear that deliberate questioning "outside Miranda" may lead to an involuntary statement. Officers who violate Miranda and obtain a statement that is later ruled involuntary may jeopardize a prosecution because the statement and, likely, its fruits will be inadmissible for any

Miranda." It simply has an evidentiary consequence - a "price" - that may be internalized by prosecutors and police. See, e.g., SOURCEBOOK, supra note $21, \S 7.48 \mathrm{~b}$ (Rev. July 1998) ("I]f you fail to comply with the Miranda guidelines in a non-coercive way, although any statement you obtain will be inadmissible at trial to prove guilt (i.e., in the prosecution's 'case-in-chief'), that is the only 'penalty.' "); SOURCEBOOK, supra note $21, \S 7.40 \mathrm{~b}$ (Rev. Mar. 1997) ("[T]he Miranda decision is not a code of conduct setting forth how police must conduct their investigations in the field."); Videotape, supra note 21, transcript reprinted in Weisselberg, supra note 3, at 191 ("[Miranda is] a court-created decision that affects the admissibility of testimonial evidence and that's all it is. ... The only consequence of your talking to somebody who has invoked his rights is we will not be able to use his statement in the case in chief in trial against him.").

184. As Davies explains, there is a sharp discontinuity in liability when a sanctioning penalty is in place. Actors nearing the line separating permissible and forbidden conduct will not balance costs and benefits in the margin, but will tend to conform to the rule. See Davies, supra note 182, at 1290-92. Here, especially, Davies heavily draws upon the work of Robert Cooter. See id. at $1291 \mathrm{nn} .65-69$ and accompanying text; Robert Cooter, Prices and Sanctions, 84 COLUM. L. REV. 1523 (1984).

185. See Davies, supra note 182, at 1296-97, 1314-15.

186. Applying Davies' theory, it may be that Miranda's legal obligation is not backed by a sufficiently strong penalty to gain the incentive effects of characterizing the exclusionary rule as a sanction instead of a price. If the sanction is not strong, actors nearing the line between permissible and impermissible conduct will not be deterred from simply balancing their own costs and benefits in the margin. 
purpose. ${ }^{187}$ For this to prove a realistic deterrent, however, courts would have to be willing to find involuntariness far more frequently than at present. In Henry v. Kernan, the Ninth Circuit seemed to understand the powerful psychological impact of questioning over a Miranda invocation, telling a suspect that he can have an attorney and then affirmatively denying the request for one. ${ }^{188}$ But unless many other courts find statements involuntary on similar facts, this will be unlikely to alter the way that many officers conduct stationhouse interrogations. Indeed, law enforcement training was not substantially modified after the court of appeals decided Henry.

A more plausible candidate for change agent is 42 U.S.C. $\S 1983$. As we have seen, the ruling in Butts appears to have prompted many state and local officials to alter their training. Even so, it is difficult to conclude that the risk of civil rights liability - or more precisely, police training about the risk of civil rights liability - can alone transform interrogation practices. Few suspects who are questioned "outside Miranda" are likely to sue police; the suspects rarely will be sympathetic plaintiffs, and the amount of damages will probably be small. ${ }^{189}$ Further, departments will most likely indemnify the defendant officers, making the possibility of financial loss for any individual officer quite slim. The risk of $\S 1983$ liability, however, is much more apt to alter police behavior in the stationhouse if it encourages sheriffs, police chiefs, and department supervisors to follow Miranda (perhaps in an effort to avoid municipal liability, the cost of defending lawsuits, or humiliation), and if these leaders endeavor to make compliance with Miranda a departmental norm.

Training is not likely to change longstanding interrogation practices within a law enforcement agency without substantial reinforcement, particularly if officers understand that courts will still allow limited use of an "outside Miranda" statement. If supervisors wish to imbue respect for Miranda, they must themselves take Miranda seriously and signal that they prefer their officers to honor an invocation, even when doing so means losing an opportunity to gain useful information or evidence. And the message must be reinforced, if necessary, through discipline of errant officers. The risk of $\$ 1983$ liability may influence conduct within a department, but ultimately a change in culture must be brought on by police themselves.

187. See supra notes $77-80$ and accompanying text.

188. See 197 F.3d 1021, 1028 (9th Cir. 1999) (noting that the officer "took unfair advantages" of the compelling pressures inherent in a custodial interrogation, and that "[a]ny minimally trained police officer should have known such pressure was improper and likely to produce involuntary statements").

189. Cf. Perrin et al,, supra note 87 , at $739-40$ (discussing why few victims of Fourth Amendment violations sue under $\S 1983$ ). 
Fieldwork seems to support this conclusion. In the early 1960s, Jerome Skolnick closely observed officers in the Oakland Police Department. ${ }^{190}$ His observations took place less than a decade after California adopted an exclusionary rule for Fourth Amendment violations. ${ }^{191}$ Skolnick concluded that the norms within police organizations "are more powerful than court decisions in shaping police behavior and that actually the process of interaction between the two is what accounts ultimately for how police behave." 192 From Skolnick's perspective, as long as an officer could justify a search to organizational superiors, the worst the officer could expect from an illegal search would be the loss of a conviction. Further, if the search turned up contraband, the "moral burden" would shift to the suspect and the illegality of the search would likely be tempered by the discovery of the evidence. ${ }^{193}$ Between 1984 and 1988, Skolnick and his colleague, Jonathan Simon, conducted additional observations in Oakland. They concluded that officers' adherence to the Fourth Amendment had improved significantly. ${ }^{194}$ They credited the change to procedures throughout "the policing enterprise" designed to enforce the values of the Fourth Amendment and noted that " $[\mathrm{t}]$ he idea of enforcing the Fourth Amendment has become normalized." 195 Training in departmental and legal rules was an important part of the change, but it was only a part. ${ }^{196}$ At about the same time that Simon and Skolnick returned to Oakland, Myron Orfield Jr. surveyed law enforcement officers in Chicago; $95 \%$ of the responding officers stated that police sometimes lied in court to avoid suppression. ${ }^{197}$ More re-

190. His observations are published in JEROME H. SKOLNICK, JUSTICE WITHOUT TRIAL (3d ed. 1994).

191. California adopted its rule in People v. Cahan, 282 P.2d 905 (Cal. 1955), six years before the United States Supreme Court decided Mapp v. Ohio, 367 U.S. 643 (1961), and applied the exclusionary rule to all the states.

192. SKOLNICK, supra note 190 , at 214.

193. Id. at 215.

194. See Jonathan Simon \& Jerome H. Skolnick, Federalism, the Exclusionary Rule, and the Police, in POWER DIVIDED: ESSAYS ON THE THEORY AND PRACTICE OF FEDERALISM 75, 80 (Harry N. Scheiber \& Malcolm M. Feeley eds., 1989).

195. Id.; see also SAmuel Walker, TAming the System: The Control of DISCRETION IN CRIMINAL JUSTICE 1950-1990 at 152-53 (1993) (describing how agency officials develop their own group norms about how things should be done, which are highly resistant to externally imposed changes).

196. In addition to police training, other important parts of the change in departmental norms included: greater involvement of prosecutors with police; increased visibility of police practices; police managers' acceptance of legal norms as a mechanism for controlling line officers; and use of suppression hearings to reinforce police appreciation for legal procedures. See Simon \& Skolnick, supra note 194, at 80-85.

197. See Myron W. Orfield, Jr., Comment, The Exclusionary Rule and Deterrence: An Empirical Study of Chicago Narcotics Officers, 54 U. CHI. L. REV. 1016, 1049 n.128 (1987). The question was whether the respondents knew of any case in which a judge has "disbelieved police testimony at a suppression hearing." Id. A subsequent question asked how of- 
cently, Orfield surveyed judges, prosecutors and public defenders in Chicago. He reported that judges and public defenders believe that perjury is the major factor limiting the deterrent effect of the exclusionary rule. ${ }^{198}$ Further, $38 \%$ of his respondents think that police supervisors encourage perjury, and $67 \%$ of respondents believe that supervisors tolerate perjury. ${ }^{199}$ These reports confirm that culture and leadership do matter.

If improper interrogation practices will not end without a change in departmental culture, direction from the top is particularly important. It is significant that a number of agency heads issued orders after Butts, instructing officers not to question "outside Miranda." Whether these orders actually become norms internalized by detectives and supervisors who work in the stationhouse will depend upon continuing training and reinforcement at all levels of the agency.

Finally, one might explore whether it is possible to determine the impact of Dickerson apart from Butts. Dickerson confirms the view, expressed in Butts, that Miranda imposes affirmative obligations. Several agencies have instructed officers to comply with Miranda after Dickerson. And, certainly, Butts would not remain on the books had Dickerson come out the other way. Yet the language of many of the training materials leaves the strong impression that, but for the possibility of civil liability, training would not have changed.

\section{B. Section 1983 Litigation After Dickerson}

If it is true that the prospect of civil rights liability significantly encourages police to comply with Miranda's commands, we should ask whether Dickerson will facilitate this use of the civil rights laws.

Prior to Dickerson, most courts rejected efforts to assess liability for Miranda violations under the federal civil rights statute, 42 U.S.C. $\S 1983$. The statute establishes a cause of action for state actors who deprive people of rights "secured by the Constitution and laws." ${ }^{200}$ As

ten judges were "right in disbelieving police testimony"; no officer answered "never." Id. at 1050 n.129.

198. See Orfield, supra note 87 , at 98.

199. Id . at 108 . According to Orfield, $29 \%$ of the respondents believe that police superiors discourage perjury, but that many in this category suggested that the efforts at discouragement were pro forma at best. $I d$. at 109.

200. Section 1983 provides, in relevant part:

Every person who, under color of any statute, ordinance, regulation, custom, or usage, of any State or Territory or the District of Columbia, subjects, or causes to be subjected, any citizen of the United States or other person within the jurisdiction thereof to the deprivation of any rights, privileges, or immunities secured by the Constitution and laws, shall be liable to the party injured in an action at law, suit in equity, or other proper proceeding for redress.

42 U.S.C. $\S 1983$ (1995). Bivens v. Six Unknown Named Agents of Federal Bureau of Narcotics, 403 U.S. 388 (1971), provides a counterpart for people whose constitutional rights have been violated by federal officials. 
Susan Klein and others explain, the Supreme Court's characterization of Miranda as "prophylactic" - arguably "nonconstitutional" - has been a main obstacle to using the civil rights law to enforce Miranda;, the federal courts have generally ruled that the failure to administer Miranda warnings or honor an invocation of the right to counsel is not itself cognizable under $\S 1983 .{ }^{202}$ Another obstacle has been the position taken by several circuits that a Fifth Amendment violation occurs only after a statement is introduced in court. ${ }^{203}$ This would limit the utility of $\$ 1983$ by restricting its application to cases where an accused was questioned in violation of Miranda and was subsequently indicted or tried.

Dickerson may well lead courts to revisit the first (though not the second) of these obstacles to civil rights liability. Dickerson acknowl-

201. See Susan R. Klein, Miranda Deconstitutionalized: When the Self-Incrimination Clause and the Civil Rights Act Collide, 143 U. PA. L. REV. 417, 421-22 (1994) (noting, however, other obstacles to the application of $\S 1983$ ); see also Martin R. Gardner, Section 1983 Actions Under Miranda: A Critical View of the Right to Avoid Interrogation, 30 AM. CRIM. L. REV. 1277, 1294-97 (1993) (noting the cases that hold that Miranda is not a "right" guaranteed by the Constitution, and so a violation cannot be raised under $\$ 1983$ ).

202. See, e.g., Jones v. Cannon, 174 F.3d 1271, 1290-91 (11th Cir. 1999) (stating that failure to warn or honor an invocation violates only a prophylactic rule, and does not support a $\S 1983$ suit); Deshawn E. v. Safir, 156 F.3d 340, 346 (2d Cir. 1998) (no liability under $\S 1983$ for failure to give Miranda warnings); Mahan v. Plymouth County House of Corrections, 64 F.3d 14, 17 (1st Cir. 1995) (same); Neighbour v. Covert, 68 F.3d 1508, 1510 (2d Cir. 1995) (same); Giuffre v. Bissell, 31 F.3d 1241, 1256 (3d Cir. 1994) (same); Lucero v. Gunter, 17 F.3d 1347, 1350-51 (10th Cir. 1994) (same); Brock v. Logan County Sheriff's Dep't of Ark., 3 F.3d 1215, 1217 (8th Cir. 1993) (same); Cooper v. Dupnik, 963 F.2d 1220, 1244 (9th Cir.) (no cause of action for "benign" questioning in violation of Miranda), cert. denied, 502 U.S. 868 (1992); Warren v. City of Lincoln, Nebraska, 864 F.2d 1436, 1442 (8th Cir.) (en banc) (no liability for failure to warn or honor invocation), cert. denied, 490 U.S. 1091 (1989); Bennett v. Passic, 545 F.2d 1260, 1263 (10th Cir. 1976) (same); see also Hutsell v. Sayre, 5 F.3d 996, 1005 n.13 (6th Cir. 1993) (citing Hensley with approval for the proposition that "a Miranda violation, without additional evidence of police coercion giving rise to a constitutional violation, does not state a cause of action under $\$ 1983$ "), cert. denied, 510 U.S. 1119 (1994); Hensley v. Carey, 818 F.2d 646, 650 (7th Cir. 1987) (citing Bennett with approval), cert. denied, 484 U.S. 965 (1987).

203. Compare Deshawn E., 156 F.3d at 348 (noting that a Miranda violation that amounts to actual coercion based on outrageous governmental conduct can be basis for $\S$ 1983 suit, even though statement was not used in court), Weaver v. Brenner, 40 F.3d 527, 535 (2d Cir. 1994) (liability where statement introduced at any criminal proceeding), and Cooper, 963 F.2d at 1242-43 (holding that plaintiff can allege Fifth Amendment cause of action even though statement was not used in court), with Giuffre, 31 F.3d at 1256 (agreeing with dissent in Cooper), Wiley v. Doory, 14 F.3d 993, 998 (4th Cir. 1994) (holding that privilege against self-incrimination is not violated until evidence is admitted in a criminal case), and Davis v. City of Charleston, Missouri, 827 F.2d 317, 322 (8th Cir. 1987) (finding no liability for failure to give Miranda warnings where statement not introduced at trial).

Cases holding that a Fifth Amendment violation may occur only when a statement is actually introduced at trial seem contrary to decisions such as New Jersey $v$. Portash, 440 U.S. 450 (1979) (affirming reversal of conviction where defendant stayed off the stand because of threatened impeachment use of immunized testimony), and Lefkowitz $v$. Cunningham, 431 U.S. 801 (1977) (striking down statute that divested official of his political office after he invoked the Fifth Amendment; no criminal charges were filed).

My own view is that a Fifth Amendment violation occurs in the stationhouse but may occur again in court. See Weisselberg, supra note 3, at 179-81. 
edges the "prophylactic" label, but expressly rejects the Fourth Circuit's conclusion "that the protections announced in Miranda are not constitutionally required." 204 Dickerson calls Miranda's procedures a mandatory constitutional "rule," which Justice Scalia claims is something short of a "right." While the majority's failure to find that a breach of Miranda is a per se Fifth Amendment violation may be driven by efforts to retain Miranda's current exclusionary rule, ${ }^{205}$ the issue here is whether this matters in applying $\S 1983 .{ }^{206}$

Dickerson sheds some light on the issue by acknowledging the Court's earlier holding in Withrow v. Williams, ${ }^{207}$ that Miranda violations may be raised on federal habeas corpus. The federal habeas corpus statute provides relief for people held "in custody in violation of the Constitution or laws... of the United States."208 According to Chief Justice Rehnquist, Withrow "obviously assumes that Miranda is of constitutional origin." 209 There is a strong argument that a mandatory "rule" that is "of constitutional origin" is indeed a "right" "secured by the Constitution." If someone convicted in violation of Miranda is in custody "in violation of the Constitution," a person denied the protections of Miranda ought to be deemed denied a "right" "secured by the Constitution." It is uncertain how this question will now play out in the circuits, though Dickerson certainly augments the argument in favor of using $\$ 1983$ to vindicate Miranda. ${ }^{210}$

204. Dickerson v. United States, 120 S. Ct. 2326, 2333 (2000).

205. See supra notes $77-83$ and accompanying text.

206. The question clearly weighs on the mind of Justice Scalia, who asked during the Dickerson argument: "Now, do you think that a policeman who fails to Mirandize the suspect, obtains a confession without having Mirandized them and then introduces that confession in court, is subject to suit? Do you know of any suit that has ever been brought?" Transcript of Oral Argument, Dickerson v. United States, 2000 U.S. TRANS LEXIS 41, at *2-3 (Apr. 19, 2000).

207. 507 U.S. 680 (1993).

208. 28 U.S.C. $\$ 2254(a)$.

209. Dickerson, 120 S. Ct. at 2333 n.3.

210. One additional point bears mentioning. Evan Caminker has suggested that, under City of Boerne v. Flores, 521 U.S. 507 (1997), Congress might lack the power to impose civil liability upon police officers for interrogations that violate Miranda. When Congress enacts laws to remedy or prevent constitutional violations, " $[t]$ here must be a congruence and proportionality between the injury to be prevented or remedied and the means adopted to that end." Id. at 520. Dickerson should ease the burden of establishing congruence and proportionality. By rejecting the characterization of Miranda's procedures as nonconstitutional prophylactic rules - and, particularly, by its treatment of Withrow - the Court made it more apparent that civil rights lawsuits for Miranda violations are suits to remedy the specific denial of constitutional rights. Thus, the civil rights remedy would be directly based upon constitutional violations as defined by the Court and City of Boerne should prove no obstacle. See Kimel v. Florida Bd. of Regents, 528 U.S. 62, 80-86 (2000) (finding that a statute failed to meet the congruence and proportionality test because it prohibited substantially more employment decisions than would be held unconstitutional under the Court's precedents). Further, to the extent that the laws permit damage actions (as opposed to actions seeking declaratory or injunctive relief), there should be little difficulty establishing propor- 
There is another useful way of thinking about Miranda and $\S 1983$, however. While the courts of appeals have thus far not been kind to the claim that Miranda violations standing alone are cognizable under $\S 1983$, most would agree that officers and cities may be sued for using coercion to obtain a statement. ${ }^{211}$ Yet a failure to advise a suspect of the right to remain silent or to speak with a lawyer has long been held to be probative of actual coercion. In Davis v. North Carolina, ${ }^{212}$ the Court ruled a confession involuntary under the Fourteenth Amendment, stating:

[T] hat a defendant was not advised of his right to remain silent or of his right respecting counsel at the outset of interrogation, as is now required by Miranda, is a significant factor in considering the voluntariness of statements later made. This factor has been recognized in several of our prior decisions dealing with standards of voluntariness. Thus, the fact that Davis was never effectively advised of his rights gives added weight to the other circumstances described below which made his confessions involuntary. ${ }^{213}$

In Butts, the Ninth Circuit found that the failure to comply with Miranda may be a significant part of a civil rights plaintiff's proof of coercion, and that officers who deliberately question "outside Miranda" are not entitled to qualified immunity. ${ }^{214}$ By reaffirming the connection between Miranda and the Constitution, Dickerson strengthens these conclusions. After Butts and Dickerson, it should be much easier for a civil rights plaintiff to get to trial if she was questioned in violation of Miranda and there is at least some additional evidence tending to show coercion. The plaintiff should be able to avoid summary judgment - a Miranda violation should, standing

tionality. Finally, the civil rights remedy would be directed only to state actors, police officers and municipalities that function "under color of" state law. See United States v. Morrison, 529 U.S. 598, 625-26 (2000) (holding that a statute directed at private individuals was not congruent and proportional).

211. See, e.g., Weaver v. Brenner, 40 F.3d 527, 535 (2d Cir. 1994) ( $\$ 1983$ action may be brought for use or derivative use of coerced confession in any criminal proceeding); Rex $v$. Teeples, 753 F.2d 840, 843 (10th Cir. 1985) (holding that "[e]xtracting an involuntary confession by coercion is a due process violation," actionable under $\$ 1983$ ), cert. denied, 474 U.S. 967 (1985).

212. 384 U.S. 737 (1966).

213. Id. at $740-41$ (citations omitted); see also Withrow, 507 U.S. at $693-94$ (noting that courts look at the totality of circumstances to determine whether a confession was voluntary, and those circumstances "include the failure of police to advise the defendant of his rights to remain silent and to have counsel present during custodial interrogation"); Mincey v. Arizona, 437 U.S. 385, 399-401 (1978) (finding a statement to be involuntary based in part upon the fact that the accused's request for counsel was ignored).

214. See Cal. Att'ys for Crim. Justice v. Butts, 195 F.2d 1039, 1047-49 (9th Cir. 1999); see also Rex, 753 F.2d at 843-44 (finding that the plaintiff had stated a civil rights cause of action for coercion where, among other things, he alleged a Miranda violation). 
alone, establish at least a genuine issue of material fact $^{215}$ as to actual coercion - the ultimate question of actual coercion should go to the jury, and the defendant officers should be denied qualified immunity. For this reason, Butts and Dickerson together substantially increase the threat of civil liability (or, certainly, the threat of costly litigation) for officers and departments that continue to question "outside Miranda." One hopes that this increased threat will be instrumental in encouraging police chiefs, sheriffs, and supervisors to change departmental norms.

\section{CONCLUSION}

Dickerson v. United States left Miranda standing, but with all of the exceptions and modifications that have been crafted during the last thirty-five years. As we have seen, Miranda's exclusionary rule does not give officers much of an incentive to cease questioning a suspect who invokes the right to counsel or the right to remain silent. Officers who comply will gain no further information. On the other hand, interrogators who continue to question may obtain statements useful for impeachment and they may learn about additional evidence or witnesses. For these reasons, police in California (and perhaps elsewhere) have developed the practice of questioning "outside Miranda."

This Article explores whether Dickerson and other recent Miranda decisions may bring an end to this practice. An examination of statewide and local police training materials shows that the risk of civil liability appears to be at least as significant as Dickerson in leading police agencies to instruct personnel to comply with Miranda. Miranda's exclusionary rule, even after Dickerson, remains so weak that law enforcement agencies need the additional incentive of the threat of civil rights liability to follow Miranda's procedures. Dickerson is, nevertheless, important because it confirms Miranda's constitutional foundation and may enhance the ability of civil rights plaintiffs to deter deliberate violations of Miranda.

Whether the practice of questioning "outside Miranda" will actually cease in California remains to be seen. Legislative efforts to end the practice have not yet proved successful. Training is necessary but not sufficient to lead officers to comply with Miranda. Miranda remains on the law books. Whether it will survive in the stationhouse will depend upon the inclination of sheriffs, police chiefs and supervisory personnel to make compliance with Miranda the norm in their departments. That inclination may be nourished by the palpable threat of $\S 1983$ liability but, whatever its source, it must ultimately come

215. See FED. R. CIV. P. 56(c) ("The judgment sought shall be rendered forthwith if the pleadings ... show that there is no genuine issue as to any material fact and that the moving party is entitled to a judgment as a matter of law."). 
from within the departments themselves. We cannot expect police officers to take Miranda seriously unless their leaders do as well. 


\section{APPENDIX A: \\ SAMPLE PUBLIC RECORDS ACT REQUEST \\ SENT TO A POLICE DEPARTMENT}

August 17, 2000

[Name and Address]

Dear Chief

I am writing to request release of public records, writings and documents pursuant to the Public Records Act, Cal. Gov. Code $\$ \S 6250$, et seq.

I am researching how police interrogation practices, and how litigation over the admissibility of statements, have been affected by four recent court decisions: People v. Peevy, 17 Cal.4th 1184, 73 Cal.Rptr.2d 865 (1998), Henry v. Kernan, 197 F.3d 1021 (9th Cir. 1999), California Attorneys for Criminal Justice v. Butts, 195 F.3d 1039 (9th Cir. 1999), and Dickerson v. United States, _ U.S. _, 120 S.Ct. 2326, 147 L. Ed. 2d 405 (2000). I am particularly interested in the practice of questioning "outside Miranda," and in any training about that practice in light of these cases. I therefore ask that you provide the following:

1. All training bulletins, manuals, videotapes, policies, seminar materials, case summaries and other documents relating to officers' duties under Miranda $v$. Arizona, that are dated or that were distributed on or after May 7, 1998 (the date People v. Peevy was decided);

2. All training bulletins, manuals, videotapes, policies, seminar materials, case summaries and other documents that discuss or refer to People v. Peevy, 17 Cal.4th 1184, 73 Cal.Rptr.2d 865 (1998), Henry v. Kernan, 197 F.3d 1021 (9th Cir. 1999), California Attorneys for Criminal Justice v. Butts, 195 F.3d 1039 (9th Cir. 1999), or Dickerson v. United States, _ U.S. _, 120 S.Ct. 2326, 147 L. Ed. 2d 405 (2000);

3. All training bulletins, manuals, videotapes, policies, seminar materials, case summaries and other documents that discuss or refer to the ability of officers to question a suspect in custody after he or she has invoked the right to remain silent or the right to counsel (i.e., question "outside Miranda"). 
Please note that I am not seeking copies of any police reports or motions or briefs in any individual cases. I am not seeking to obtain any reports of any individual interrogations. Rather, I am only seeking to determine, broadly, how sworn personnel have been trained in light of these decisions.

I request that you determine whether you will comply with this request within ten days, as required by Cal. Gov. Code $\$ 6253$. Please tell me whether there is any copying fee for these materials, and I will promptly provide payment. Finally, should you determine not to make all of the requested documents available, I request that you indicate which items you will not turn over for inspection and specify the reasons for refusal to comply with this request, pursuant to Cal. Gov. Code $\$ 6255$.

Thank you very much for your assistance. Please call me with any questions at all about this request.

Very truly yours,

$\mid \mathrm{s} /$

Charles D. Weisselberg 
APPENDIX B:

AgENCY RESPONSES TO PUBLIC RECORDS ACT REQUESTS

County Agencies

( $\mathrm{R}=$ Agency responded to request)

\begin{tabular}{|c|c|c|c|}
\hline \multirow[b]{2}{*}{ County } & \multirow[b]{2}{*}{$\begin{array}{l}\text { Population as } \\
\text { of April } 2000^{216}\end{array}$} & \multicolumn{2}{|c|}{ Responses Received From } \\
\hline & & $\begin{array}{c}\text { District } \\
\text { Attorney }\end{array}$ & Sheriff \\
\hline Alameda & $1,443,741$ & $\mathrm{R}$ & $\mathrm{R}$ \\
\hline Fresno & 799,407 & $\mathrm{R}$ & $\mathrm{R}$ \\
\hline Humboldt & 126,518 & $\mathrm{R}$ & \\
\hline Kern & 661,645 & & $\mathrm{R}$ \\
\hline Los Angeles & $9,519,338$ & $\mathbf{R}$ & $\mathbf{R}$ \\
\hline Orange & $2,846,289$ & $\mathbf{R}$ & \\
\hline Riverside & $1,545,387$ & $\mathbf{R}$ & $\mathrm{R}$ \\
\hline Sacramento & $1,223,499$ & & \\
\hline San Bernardino & $1,709,434$ & $\mathrm{R}$ & $\mathbf{R}$ \\
\hline San Diego & $2,813,833$ & $\mathbf{R}$ & \\
\hline San Francisco & 776,733 & & $\mathbf{R}$ \\
\hline San Joaquin & 563,598 & & \\
\hline Santa Clara & $1,682,585$ & $\mathbf{R}$ & $\mathbf{R}$ \\
\hline Shasta & 163,256 & $\mathrm{R}$ & $\mathrm{R}$ \\
\hline Total & $25,875,263$ & $10 / 14$ & $9 / 14$ \\
\hline
\end{tabular}

Response rate for District Attorneys: 71\%.

Response rate for Sheriffs: $64 \%$.

216. Population data are from the U.S. Census Bureau and are available at http://factfinder/census.gov (last visited Apr. 20, 2001). 
City Police Departments

( $\mathrm{R}=$ =Agency responded to request)

\begin{tabular}{|l|c|c|}
\hline \multicolumn{1}{|c|}{ City } & $\begin{array}{c}\text { Population, as of } \\
\text { April 2000 }\end{array}$ & $\begin{array}{c}\text { Responses } \\
\text { Received }\end{array}$ \\
\hline Bakersfield & 247,057 & $\mathrm{R}$ \\
\hline Eureka & 26,128 & \\
\hline Fresno & 427,652 & \\
\hline Los Angeles & $3,694,820$ & \\
\hline Oakland & 399,482 & $\mathrm{R}$ \\
\hline Oceanside & 161,029 & $\mathrm{R}$ \\
\hline Palm Springs & 42,807 & \\
\hline Redding & 80,865 & $\mathrm{R}$ \\
\hline Riverside & 255,156 & $\mathrm{R}$ \\
\hline Sacramento & 407,018 & $\mathrm{R}$ \\
\hline San Bernardino & 185,401 & \\
\hline San Diego & $1,223,400$ & $\mathrm{R}$ \\
\hline San Francisco & 776,733 & $\mathrm{R}$ \\
\hline San Jose & 894,943 & $\mathrm{R}$ \\
\hline Santa Ana & 337,977 & \\
\hline Stockton & 243,771 & $\mathrm{R}$ \\
\hline \multicolumn{1}{|c|}{ Total } & $9,404,239$ & $10 / 16$ \\
\hline
\end{tabular}

Response rate: $62.5 \%$.

217. Population data are from the U.S. Census Bureau and are available at http://factfinder/census.gov (last visited Apr. 20, 2001). 